\title{
ERGÄNZUNGEN ZU EINER PERSONALBIBLIOGRAFIE ÁRMIN(IUS) VÁMBÉRY*
}

\author{
Sebastian CWIKLINSKI \\ Institut für Turkologie, Freie Universität Berlin \\ Fabeckstr. 23-25, 14195 Berlin, Deutschland \\ e-mail: sebastian.cwiklinski@web.de
}

The paper offers additions to Michael Knüppel's bibliography from 2017 on the Hungarian Orientalist Ármin Vámbéry (1832-1913). Following Knüppel's guidelines, the bibliographical entries are given in three sections: publications by Vámbéry himself, works about him, and finally reviews of his works.

Key words: Vámbéry Ármin (1832-1913), Turkology, Oriental Studies, Islamic studies, bibliography.

In einer Besprechung des 2017 in zweiter Auflage erschienenen Versuchs einer Personalbibliographie Ármin Vámbérys (Knüppel 2017) ${ }^{1}$ hatte ich bereits festgestellt, dass Michael Knüppel, der Herausgeber der Bibliografie, zwar sorgfältig gearbeitet habe, mit Sicherheit aber noch weitere Schriften des ungarischen Orientalisten zu finden sein würden. Aus diesem Befund heraus entstand das Vorhaben, weitere Schriften

* Ich möchte mich herzlich bei Prof. Melek Çolak, Prof. Cavid Qasımov, Prof. Ėleonora Šafranskaja und Dr. Gülay Tulaşoğlu für die Zusendung ihrer Publikationen zu Ármin Vámbéry bedanken. Dr. Miklós Sárközy hat mir nicht nur seine eigenen Artikel zum ungarischen Turkologen zugesandt, sondern auch den von ihm 2015 herausgegebenen Sammelband mit den wichtigsten Ergebnissen der Vámbéry-Forschung des letzten Jahrzehnts in ungarischer Sprache. Darüber hinaus hat er mir viele wichtige Hinweise auf weitere Publikationen gegeben und alle meine Fragen geduldig beantwortet; für diese Hilfe sei ihm herzlich gedankt. Prof. István Zimonyi gilt mein Dank für wichtige Informationen zu seinen Vámbéry-Artikeln, den Mitarbeiterinnen und Mitarbeitern der Staatsbibliothek Preußischer Kulturbesitz Berlin für die Gewährung des Zugangs zu Literatur, deren Erhaltungszustand eine Nutzung schwierig erscheinen ließ.

${ }^{1}$ Die erwähnte Rezension ist zur Veröffentlichung angenommen in Orientalistische Literaturzeitung (Berlin). 
von und über Vámbéry bibliografisch zu erfassen; die Ergebnisse dieser Arbeit sollen hier nun vorgestellt werden. Knüppel hatte festgehalten, dass die Idee der Vollständigkeit einer Vámbéry-Bibliografie angesichts der Tatsache, dass der ungarische Orientalist seine Werke an vielen, auf den ersten Blick abseitigen Orten veröffentlicht hatte, ein in weiter Ferne liegendes und vielleicht nie zu erreichendes Ziel sei. Diesem Befund kann ich auch nach einer längeren Arbeit an der folgenden Bibliografie nur zustimmen. Im Folgenden sei näher erläutert, warum wir von einer vollständigen Erfassung des Schrifttums von und über Ármin Vámbéry noch weit entfernt sind.

Bei der Erfassung des noch nicht in Michael Knüppels Bibliografie aufgeführten Vámbéry-Schrifttums wurden zunächst die Bibliothekskataloge derjenigen Länder konsultiert, in denen eine größere Anzahl an Schriften von und über den ungarischen Turkologen zu erwarten war. Anschließend wurde in den digitalen (Zeitungs-, Zeitschriften- und monografischen) Bibliotheken dieser und weiterer Länder nach Schriften von Vámbéry gesucht und ermittelte Schriften auch in Bibliotheken konsultiert. In einem dritten Schritt wurde versucht, Schriften ausfindig zu machen, die an anderer Stelle erwähnt werden, und schließlich wurden auch Spezialbibliografien entweder zu einzelnen Publikationen oder zu den einschlägigen Regionen zu Rate gezogen. Bei diesem letzten Schritt wurde ich mit bibliografischen Informationen von sehr unterschiedlicher Qualität konfrontiert: Während sich etwa Ferenc Galambos' Repertorium der ungarischen Wochenzeitschrift Vasárnapi Ujság (Galambos 1978-1979) als sehr zuverlässig erwies und einige neue Einträge für die vorliegende Bibliografie erbrachte, waren bei den Turkestan- und Asienbibliografien Vladimir Mežovs (18301894) Abstriche zu machen. Mežov hatte von 1867 bis 1887 in Sankt Petersburg in einer 416 Bände umfassenden Ausschnittsammlung (Turkestanskij Sbornik) Turkestan betreffende Literatur zusammengestellt und diese auch in einer dreibändigen Bibliografie (Mežov 1878, 1884 und 1888) aufbereitet, wobei die Angaben in der Bibliografie nicht über die Informationen in den einzelnen Bänden der Ausschnittsammlung hinausgehen und oft unvollständig, manchmal auch falsch sind. ${ }^{2}$

So mancher Vámbéry betreffende Zeitungstext aus den Bänden des Turkestanskij Sbornik, die mittlerweile digitalisiert und online zugänglich sind ${ }^{3}$, konnte deshalb für die vorliegende Bibliografie nicht berücksichtigt werden. Einzelne Artikel aus Mežovs Sammelbänden habe ich jedoch trotz dieser Kritik übernommen, wenn die Texte wichtig genug erschienen, um in eine Vámbéry-Bibliografie aufgenommen zu werden. Anderenfalls hätte etwa die zwischen Vladimir Grigor'ev und Eugene

${ }^{2}$ So ist etwa im 20. Band des Turkestanskij Sbornik (Sanktpeterburg 1870) auf den Seiten 209 bis 211 ein Artikel Vámbérys „Die russische Handelsstraße auf der Ostküste des Kaspischen Meeres“ mit der Information „Allgemeine Zeitung 1867 N 34 (Beilage)“ zu finden, der von Mežov später auch dementsprechend bibliografiert wurde (Mežov 1878, S. 107, Nr. 1384). Die Überprüfung dieser Angaben zeigte, dass der Artikel nicht 1867, sondern 1870 in der genannten Nummer der Zeitung erschienen ist. Auch andere Informationen im Turkestanskij Sbornik bzw. den entsprechenden Bibliografien waren falsch. So wird etwa im 1869 erschienenen 4. Band der Sammlung ein Text Vámbérys mit dem Erscheinungsjahr 1873 aufgeführt.

${ }^{3}$ URL http://ts.manas.edu.kg [letzter Zugriff: 06.02.2019]. 
Schuyler 1874 in der Zeitung Birževye Novosti geführte Diskussion über die Wahrhaftigkeit von Vámbérys Angaben nicht erfasst werden können, obwohl die Texte von mir eingesehen werden konnten. Gleichwohl musste der Tatsache Rechnung getragen, dass Mežovs Informationen zu den von ihm gesammelten Texten den Ansprüchen an eine wissenschaftliche Bibliografie nicht genügen; dies wurde getan, indem den entsprechenden Einträgen in der Bibliografie die Information über den jeweiligen Fundort in den Bänden des Turkestanskij Sbornik beigegeben wurde. Darüber hinaus wurden die Einträge jeweils an das Ende eines Jahres gestellt, um ihren gesonderten Status herauszustellen. Ich verstehe die Informationen zu den fraglichen Titeln gleichzeitig auch als Aufruf an die Kolleginnen und Kollegen, diese Angaben zu überprüfen, zu ergänzen und gegebenenfalls zu korrigieren! Entsprechendes gilt auch für die Texte von beziehungsweise über Vámbéry, die ich nicht einsehen konnte (was jeweils bei den entsprechenden Einträgen vermerkt wird), bei denen mir die vorliegenden bibliografischen Angaben aber verlässlich genug erschienen, um sie in die Bibliografie aufzunehmen.

Da ich die vorliegende Bibliografie ausdrücklich als Ergänzung zu Michael Knüppels verdienstvoller Zusammenstellung sehe, habe ich mich in technischer Hinsicht weitgehend an seinen Vorgaben orientiert: Die Einträge werden in die drei Rubriken Schriftenverzeichnis Árminius Vámbéry, Biografisches und Rezensionen von Werken des ungarischen Turkologen eingeteilt. Innerhalb eines Jahres werden zunächst monografische, anschließend abhängige Veröffentlichungen jeweils alphabetisch aufgeführt; geändert habe ich lediglich, dass nun nicht mehr nur die deutschen, englischen und französischen, sondern nun auch der ungarische Artikel a/az und der niederländische Artikel bei der alphabetischen Einordnung unberücksichtigt bleiben. In der Frage, was für Texte Aufnahme in eine Vámbéry-Bibliografie finden und wie sie aufgenommen werden sollten, folge ich wiederum weitgehend der Linie Michael Knüppels. Bezeichnungen wie „Nr. 195“ beziehen sich auf von Knüppel erfasste Publikationen Vámbérys, während Hinweise wie „Nr. 4.1.867“ auf in dessen Bibliografie aufgeführte Veröffentlichungen zum ungarischen Turkologen verweisen.

Wie könnte es nun weitergehen? Bei der Arbeit an der Bibliografie zeigte sich schließlich, dass größere Fortschritte bei der Erfassung des Schrifttums von Ármin(ius) Vámbéry nur in Zusammenarbeit mit Spezialistinnen und Spezialisten derjenigen Länder zu erzielen sein werden, die im Leben des ungarischen Orientalisten eine wichtige Rolle spielten, also Ungarns, der Türkei, Russlands (hier auch der russischen Teilrepublik Tatarstan), Indiens und Pakistans. Mehr als einmal blieb die Suche nach einem Text Vámbérys ohne Ergebnis, weil bestimmte Veröffentlichungen in Deutschland nicht verfügbar waren. ${ }^{4}$ Es steht zu hoffen, dass der vorliegenden Bibliografie, die sich als Ergänzung zu einem wichtigen Baustein in der Vámbéry-Forschung versteht, weitere Ergänzungen und Korrekturen folgen werden.

${ }^{4}$ So ist etwa die Mehrzahl der Bände zu den jährlich abgehaltenen Vámbéry-Konferenzen in Dunaszerdahely - eine der wichtigen Möglichkeiten, sich über den aktuellen Stand der Forschung zum ungarischen Orientalisten zu informieren -, in deutschen Bibliotheken nicht zu finden. 


\section{Ergänzungen zum Versuch einer Personalbibliografie}

\section{Schriftenverzeichnis Armin(ius) Vámbéry}

1860

1. Török történetirók előadása magyar eseményekről. Pecsévi török történetiró kéziratából forditotta Vámbéry Armin [dt. „Die Darstellung ungarischer Geschehnisse durch türkische Geschichtsschreiber. Aus der Handschrift des türkischen Geschichtsschreibers Pečevi übersetzte Ármin Vámbéry“"]. In: Vasárnapi Ujság Jg. 7, Nr. 8, v. 19.2.1860, coll. 90 a-91 b; Jg. 7, Nr. 10, v. 4.3.1860, coll. 110 b-111 b.

\section{5}

1. Das Hauptstadtleben in Bochara. In: Das Ausland Jg. 38, Nr. 46, v. 18.11.1865, coll. 1081 a1086 a.

2. On the Origin of the Hungarians. In: The Ethnological Journal Bd. 1, Nr. 4 (Oktober 1865), pp. $147-157$.

\section{6}

1. Očerki žizni v Buchare. In: Literaturnaja biblioteka Bd. 1, Nr. 1 (1866) [hat nicht vorgelegen].

2. Palatka i ee obitateli. In: Literaturnaja biblioteka Bd. 1, Nr. 1 (1866), pp. 23-31; Nr. 2 (1866), pp. 125-131 [hat nicht vorgelegen].

3. Scènes et tableaux du monde asiatique. In: Revue Britannique Bd. 3 (1866), pp. 75-88.

4. Wyjątek z podróży Hermana Vambery do Chiwy i Buchary [dt. „Auszug aus der Reise Hermann Vámbérys nach Chiva und Buchara"]. In: Wędrowiec Serie I, Bd. 8, Nr. 202, v. 15.11.1866, coll. 305 a-310 a; Nr. 203, v. 22.11.1866, coll. 321 a-324 a; Nr. 204, v. 29.11 .1866 , coll. 342 b-347 b; Nr. 205, v. 6.11.1866, coll. 363 b-366 b.

5. Das Zelt und seine Bewohner. In: Das Ausland Jg. 39, Nr. 8, v. 20.2.1866, coll. 171 b-174 a.

6. Karavan v stepi. In: Literaturnaja biblioteka Bd. 1, Nr. 5 (1866).

> Turkestanskij Sbornik 1867 Bd. 4, Sanktpeterburg, 1869, pp. 291-299.

1. Putešestvie po Srednej Azii iz Tegerana čerez Turkmenskuju pustynju po vostočnomu beregu Kaspijskogo morja v Chivu, Bucharu i Samarkand, predprinjatoe v 1863 godu s naučnoju celju, po poručeniju Vengerskoj akademii v Pešte, členom ee A. Vámbéri. Moskva, 1867: A. I. Mamontov, XVI +369 pp.

2. Aziatskaja pustynja (Meždu Kaspijskim morem i Amu-Dar'ej). In: Lichačeva, E./Suvorina, A. (Hrsg.): Velikie javlenija i očerki prirody. Geografičeskaja chrestomatija Bd. 2, Sanktpeterburg, 1876, pp. 324-336 [Auszüge aus Nr. 43].

3. Egy Gazella-vadászat Perzsiában [dt. „Eine Gazellenjagd in Persien“]. In: Lázár, Kálmán (Hrsg.): Természetbarátok és vadászok évkönyve, Pest, 1867, pp. 247-249. 
4. Iz Tegerana v Trapezunt. In: Literaturnaja Biblioteka Bd. 11, Nr. 21 (1867), pp. 61-70 [hat nicht vorgelegen].

5. Ot Mešgeda do Tegerana. In: Literaturnaja Biblioteka Bd. 8, No. 15-16 (1867), pp. 126143 [hat nicht vorgelegen].

6. Soperničestvo Rosii i Anglii v Srednej Azii. In: Zapiski dlja čtenija Nr. 12 (1867), pp. $192-$ 224 [Übers. v. Nr. 96].

7. V stolice Chorassana. In: Literaturnaja Biblioteka Bd. 5, Nr. 7-8 (1867), pp. 141-151.

8. Torgovlja rabami i žizn' rabov v Srednej Azii. In: Otečestvennye Zapiski Bd. 172, Teil 12 (1867), pp. 202-215 [hat nicht vorgelegen, Übers. v. Nr. 98].

\section{8}

1. Očerki Srednej Azii. Moskva, 1868: A. I. Mamontov, IV + 361 pp. [Übersetzung von Nr. 103].

2. Chiwa. In: Wędrowiec Serie I, Bd. 12, Nr. 288, v. 9.7.1868, coll. 26 b-28 a; Nr. 289, v. 16.7.1868, coll. 38 a -40 a.

3. The First Book in Turkish. In: The Book Worm Bd. 3 (1868), pp. $86-87$ [vgl. Nr. 113].

4. Gorod Samarkand (iz Vamberi). In: Vsemirnyj Putešestvennik Bd. 3, Nr. 21 (1868), pp. $332-335$.

5. Kleider und Schmuckgegenstände der ostislamitischen Völker. In: Westermann's Illustrirte Monatshefte Nr. 50 (146) (November 1868), pp. 152-163.

6. Pis'mo A. Vamberi k redaktoru gazety „Times“. In: Birževye vedomosti Nr. 92 (1868), p. 92 [hat nicht vorgelegen].

7. Reizen door Midden-Azië, von Teheran door de Turkmanische Woestijn aan de oost der Kaspische Zee naar Chiwa, Boechara, en Samarkand [dt. „Reisen durch Mittelasien, von Teheran durch die turkmenische Wüste bis zum Osten des Kaspischen Meeres bis Chiwa, Buchara und Samarkand“"]. In: Rietstap, J. B. (Hrsg.): De Wereldbol. De jongste zee- en landreizen, volgens Dr. W. Harnisch, F. Heinzelmann en anderen aan Neêrlands volk verhaald Bd. 4, Groningen o. J. [ca. 1868]: P. Noordhoff, pp. 93-216.

8. Die Rivalität zwischen England und Rußland in Mittelasien. In: Allgemeine Zeitung Nr. 265, v. 21.9.1868, coll. 4014 b-4015 a.

9. Gorod Buchara. In: Vest'Nr. 100 (1868).

> Turkestanskij Sbornik 1868 Bd. 6, Sanktpeterburg, 1869, p. 117-119.

10. Drugoe pis'mo A. Vambéri. In: Birževye Vedomosti Nr. 294 (1868).

> Turkestanskij Sbornik 1868 Bd. 8, Sanktpeterburg, 1869, p. 325.

\section{9}

1. The Hyrcanian Desert, and the Principal Roads Across It. In: Bates, H. W.: Illustrated Travels. A Record of Discovery, Geography, and Adventure Bd. 1, London, 1869, pp. 263-266.

2. On the Uigurs. In: Report of the Thirty-Eighth Meeting of the British Association for the Advancement of Science Held at Norwich in August 1868: Notices and Abstracts of Miscellaneous Communications to the Section. London, 1869, p. 141.

3. Rußlands Pläne auf die Ostküste des Kaspischen Meeres. In: Beilage zur Allgemeinen Zeitung Nr. 344, v. 30.12.1869, coll. 5621 a-5622 b.

4. Über die Handelsverhältnisse zwischen Ostindien und Ostturkestan. In: Der Welthandel 1. Jg., Nr. 5 (1869), pp. 241-245. 
1. Eigenhändiger Brief Mohamed's. In: Didaskalia. Belletristisches Beiblatt des Frankfurter Journals Nr. 171, v. 22.6.1870, ohne Seitenzahl.

2. Hayward und Shaw in Ostturkestan. In: Globus Nr. 17 (1870), pp. 265-268.

3. [Rez.]: Pavet de Courteille: Dictionnaire Turk-Oriental. Destiné principalement à faciliter la lecture des ouvrages de Baber. In: Zeitschrift der Deutschen Morgenländischen Gesellschaft Bd. 24, No. 1/2 (1870), pp. 245-247.

4. Die russische Handelsstraße auf der Ostküste des Kaspischen Meeres. In: Beilage zur Allgemeinen Zeitung Nr. 34, v. 3.2.1870, coll. 514 b-515 a.

5. Treurig lot van den duitschen geoloog Bredemayer in Birma [dt. „Das traurige Schicksal des deutschen Geologen Bredemayer in Burma“"]. In: Wetenschappelijke bladen Teil 1 (1870), pp. 313-316 [Übers. v. Nr. 145].

6. Zur Eisenfabrication in Persien. In: Das Ausland Jg. 43, Nr. 1, v. 1.1.1870, coll. 23 a-24 a.

1. Egy angol diplomata kutatási utazáson [dt. „Die Forschungsreise eines englischen Diplomaten“"]. In: Pesti Napló Nr. 155 (Morgenausgabe), v. 8.7.1871, ohne Seitenzahl.

2. Machdumkuli, ein turkomanischer Barde. In: Europa Nr. 12 (1871), coll. 361-368.

3. A szerelmes mollah (Bokharai történet) [dt. „Der verliebte Mullah. Eine Bucharaer Geschichte“]. In: Vasárnapi Ujság Jg. 18, Nr. 15, v. 9.4.1871, coll. 178 b-179 b.

1. A babona Közép-Ázsiában [dt. „Der Aberglaube in Mittelasien“]. In: Pesti Napló Nr. 212, v. 14.9.1872 (Morgenausgabe), ohne Seitenzahl.

2. Dzungária, a legújabb orosz tartomány [dt. „Die Dsungarei, die jüngste russische Provinz"]. In: Pesti Napló Nr. 12, v. 16.1.1872 (Morgenausgabe), ohne Seitenzahl.

3. The Newly-Conquered Russian Province of Dzungaria. In: Bates, Henry Walter (Hrsg.): Illustrated Travels. A Record of Discovery, Geography, and Adventure Bd. 4, London, 1872 , pp. $7-10$.

4. A Ramble in Persia. In: Bates, Henry Walter (Hrsg.): Illustrated Travels. A Record of Discovery, Geography, and Adventure Bd. 4, London, 1872, pp. 243-252, 267-271.

5. Rußlands politische Errungenschaft in Ostturkestan. In: Allgemeine Zeitung Nr. 298, v. 24.10.1872, coll. 4541 b-4542 b.

6. Superstitions in Central Asia. In: Bates, Henry Walter (Hrsg.): Illustrated Travels. A Record of Discovery, Geography, and Adventure Bd. 4, London, 1872, pp. 186-187.

7. Viaggio nell'Asia Centrale. Da Teheran a Khiva, Bokhara e Samarkand. In: Giornale popolare di viaggi Nr. 16, pp. 248-252; Nr. 17, pp. 258-259; Nr. 18, pp. 274-278; Nr. 20, pp. 314-319; Nr. 21, pp. 332 [dort fälschlicherweise: 338]-334; Nr. 22, pp. 340-346; Nr. 23, pp. $362-366$; Nr. 24 , pp. $378-383$; Nr. 25 , pp. $393-398$; Nr. 26, pp. $402-410$ [jeweils 1872; dt. „Reise in Zentralasien. Von Teheran nach Chiwa, Buchara und Samarkand“"].

8. Russkie političeskie priobretenija v vostočnom Turkestane. In: Birževye Vedomosti Nr. 284 (1872) [Übers. d. Artikels aus der Allgemeinen Zeitung v. 24.10.1872].

> Turkestanskij Sbornik Bd. 44, Sanktpeterburg, 1873, pp. 32-38. 
1. Das Ende der Chiwa-Expedition. In: Bamberger neueste Nachrichten Nr. 176, v. 1.7.1873, coll. 3 a-3 b sowie in: Augsburger Neueste Nachrichten Nr. 161, v. 9.7.1873, p. 1908 [Übers. v. Nr. 215].

2. Der geheime Vertrag zwischen Rußland und Persien. In: Beilage zur Allgemeinen Zeitung Nr. 165, v. 26.1.1873, coll. 396 a-b.

3. Nach der Einnahme Chiwa's. In: Allgemeine Zeitung Nr. 198, v. 17.7.1873, coll. 3021 b3022 a.

4. Nasr-ed-din Schah. In: Morgenpost (Wien) Nr. 150, v. 1.6.1873, ohne Seitenzahl.

5. Nasr-ed-din Schah in Wien. In: Morgenpost (Wien) Nr. 208, v. 30.7.1873, ohne Seitenzahl.

6. Die Neutralität Afghanistans und die russische Demarcations-Linie. In: Allgemeine Zeitung Nr. 44, v. 13.4.1873, coll. 653 b-655 a.

7. Die orientalische Abtheilung der Weltausstellung. In: Morgenpost (Wien) Nr. 199, v. 21.7.1873, ohne Seitenzahl.

8. The Steppes to the North of Bokhara. In: Ocean Highways: The Geographical Review May 1873 , pp. 59-65.

9. The Tekes Valley and the Muzart Pass. In: Ocean Highways: The Geographical Review June 1873, pp. 91-93.

10. Tschekischlar und die Straße nach Chorassan. In: Allgemeine Zeitung Nr. 109, v. 19.4.1873, coll. $1649 \mathrm{a}-\mathrm{b}$.

11. Der Weg über den Muzart, In: Das Ausland Jg. 46, Nr. 16, v. 21.4.1873, coll. 316 b-317 b.

12. Die Wirren in Chokand. In: Allgemeine Zeitung Nr. 278, v. 5.10.1876, coll. 4217 b-4218 b.

13. [ohne Titel]. In: Berliner Börsenzeitung Nr. 331 (Morgenausgabe), v. 19.7.1873, ohne Seitenzahl [Nachdruck d. Artikels aus der Allgemeinen Zeitung v. 17.7.1873].

14. [ohne Titel]. In: Deutsche Zeitung (Morgenblatt) Nr. 618, v. 19.9.1873, col. 4 c [an die Zeitschrift Il Diritto gerichteter Leserbrief].

\section{4}

1. Putešestvie po Srednej Azii, 2-e izdanie. Moskva, 1874: A. I. Mamontov, XIV + 383 pp.

2. The Toorkmans and Their Position towards Russia, Calcutta, 1874: Printed at the Foreign Department Press, 11 pp. [Übersetzung von Nr. 230; hat nicht vorgelegen].

3. A New Map of Central Asia. In: The Geographical Magazine November 1874, v. 1.11.1874, col. 350 a.

4. Russen und Britten [sic] in Mittelasien. In: Allgemeine Zeitung Nr. 176, v. 25.6.1874, coll. 2729 b- 2730 b.

5. Ein Tagebuch asiatischer Erlebnisse [Rez. zu: Erinnerungen aus dem Leben des kaiserlich russischen Generallieutenants Johann v. Blaramberg. Nach dessen Tagebüchern von 18111871, Berlin 1874]. In: Beilage zur Allgemeinen Zeitung Nr. 335, v. 1.12.1874, coll. 5213 a-5215 a.

6. Über einige in Chiwa herrschende Krankheiten. In: Das Ausland Jg. 47, Bd. 47, Nr. 47, v. 23.11.1874, coll. 939 a -940 b.

7. Zur mittelasiatischen Frage. In: Allgemeine Zeitung Nr. 54, v. 23.2.1874, coll. 789 a-790 a.

8. [ohne Titel]. In: Izraelita. Organ poświęcony sprawom Religji i Oświaty Jg. 9, Nr. 9, v. 9.1.1874, col. 16 a [undatierter Leserbrief an die Zeitung Diritto]. 
1. Der allerneueste russische Feldzug in Chiwa. In: Allgemeine Zeitung Nr. 101, v. 11.4.1875, coll. $1549 \mathrm{~b}-1550 \mathrm{a}$.

2. Ein deutscher Officier über Mittelasien [Rez. zu: Der russische Feldzug nach Chiwa. I. Theil. Historische und militär-statistische Uebersicht des russischen Operationsfeldes in Mittelasien. Eine militär-geographische Studie von Hugo Stumm, Berlin 1875]. In: Beilage zur Allgemeinen Zeitung Nr. 170, v. 19.6.1875, coll. $2574 \mathrm{a}-\mathrm{b}$.

3. O nekotorych boleznjach, gospodstvujuščich v Chive. In: Zdorov'e Bd. 1 (1874), pp. $148 \mathrm{ff}$. sowie in: Znanie Nr. 11-12 (1874) [beide Ausgaben haben nicht vorgelegen].

4. Sir Henry Rawlinson über die mittelasiatische Frage [Rez. zu: England and Russia in the East. A series of papers on the political and geographical conditions of Central Asia by Maj Gen Sir Henry Rawlinson, London, 1875]. In: Beilage zur Allgemeinen Zeitung Nr. 76, v. 17.3.1875, coll. $1175 \mathrm{a}-1176$ a.

5. Über die Schiffbarkeit des Oxus. In: Beilage zur Allgemeinen Zeitung Nr. 17, v. 17.1.1875, coll. 245 a-246 a.

1. Očerki žizni i nravov Vostoka, Sanktpeterburg, 1876: V. Kovalevskij, II + 576 pp. [Übersetzung von 264].

2. Der Kreuzzug im neunzehnten Jahrhundert. In: Allgemeine Zeitung Nr. 225, v. 12.8.1876, coll. $3441 \mathrm{~b}-3442 \mathrm{~b}$.

3. Russland's Handel an der Ostküste des Kaspi-Sees. In: Österreichische Monatsschrift für den Orient 12, v. 15.12.1876, pp. 181-183.

4. Ein Thronprätendent in Chokand. In: Allgemeine Zeitung Nr. 112, v. 21.4.1876, coll. 1677 b1678 a.

5. A török hirlapirodalom. In: Pesti Napló Nr. 314, v. 28.12 .1876 [hat nicht vorgelegen; dt. „Die türkische Zeitungsliteratur"].

6. Vysokaja porta v Konstantinopole. In: Novoe Vremja Nr. 140 (1876) [hat nicht vorgelegen].

7. Zur türkischen Reformfrage. In: Allgemeine Zeitung Nr. 182, v. 30.6.1876, coll. 2777 a2778 a.

1. Očerki i kartiny vostočnych nravov, Sanktpeterburg, 1877: Obščestvennaja pol'za, 279 pp.

2. Kulturskildringer fra Orienten, Kjøbenhavn, 1877: Andr. Fred. Høst \& Søns Forlag, 352 pp. [hat nicht vorgelegen; dt. „Skizzen zur Kultur des Orients“].

3. De chineezen in Oost-Turkestan [dt. „Die Chinesen in Ost-Turkestan“]. In: Sumatra-Courant. Nieuws-, Handels- en Advertentieblad Nr. 54 (1877), v. 7.7.1877, ohne Seitenzahl; Nr. 55, v. 11.7.1877, ohne Seitenzahl [Übers. d. Artikels aus der Allgemeinen Zeitung v. 19.3.1877].

4. Die Chinesen in Ost-Turkestan. In: Allgemeine Zeitung Nr. 78, v. 19.3.1877, coll. 1081 a1082 a.

5. Az irániak Turkesztánban [dt. „Die Iraner in Turkestan“]. In: Földrajzi Közlemények Bd. 5 (1877), pp. 49-51.

6. A magyar irodalom 1876-ban. In: Pesti Napló Nr. 9, v. 11.1.1877 [hat nicht vorgelegen; dt. „Die ungarische Literatur im Jahre 1876“]. 
7. Mithad Pascha - kein Jude. In: Neues Wiener Abendblatt Nr. 86, v. 29.3.1877, coll. 2 c-3 a sowie [dort unter dem Titel „Mithad Paschas Abstammung"] in: Grazer Zeitung Nr. 73, v. 31.3.1877, col. 4 a [Nachdruck e. Leserbriefes an den Pester Lloyd].

8. O żydach w Turcji [dt. „Über die Juden in der Türkei“]. In: Izraelita. Organ poświęcony sprawom Religji i Oświaty Jg. 12, Nr. 21, v. 1.6.1877, coll. 171 b-172 a [auszugsweise Übers. v. Nr. 264].

9. Russia in Central Asia. To the Editor of the „Daily Telegraph“. In: The Times of India Bd. 40 N. S., Nr. 59, v. 9.3.1877, col. 3 g.

10. [ohne Titel]. Altonaer Nachrichten Nr. 76, v. 3.4.1877, ohne Seitenzahl [Nachdruck e. Leserbriefes an den Pester Lloyd].

\section{8}

1. Az afghán nép. Ethnographiai vázlat [dt. „Das afghanische Volk. Eine ethnographische Skizze“]. In: Pesti Napló Nr. 244 (Morgenausgabe), v. 9.10.1878, ohne Seitenzahl; Nr. 245 (Morgenausgabe), v. 10.10.1878, ohne Seitenzahl.

2. Afghanisztan és az afghánok. Föld- és népismereti vázlat [dt. „Afghanistan und die Afghanen. Eine Landes- und völkerkundliche Skizze“]. In: Földrajzi Közlemények Jg. 6 (1878), pp. 353-367.

3. Az angol-afghan viszály [dt. „Der anglo-afghanische Konflikt“]. In: Pesti Napló Nr. 232 (Morgenausgabe), v. 26.9.1878; Nr. 233 (Morgenausgabe), v. 27.9.1878 [jeweils ohne Seitenzahl].

4. England and Russia in the East. To the Editor of „The Daily Telegraph“. In: The Times of India Bd. 41 N. S., Nr. 229, v. 20.9.1878, coll. 4 a-b.

5. In Central Asia. In: New Zealand Tablet Bd. 6, Nr. 289, v. 15.11.1878, coll. $11 \mathrm{a}-\mathrm{b}$ [auszugsweise Übers. v. Nr. 325].

6. Russen en Engelschen in Azië [dt. „Russen und Engländer in Asien“]. In: Bijvoegsel van De Locomotief. Samarangsch Handels- en Advertentieblad Jg. 27, Nr. 266, v. 12.11.1878, ohne Seitenzahl.

7. A Russian Attack on Asia. In: Otago Daily Times Nr. 5155, v. 26.8.1878, col. 5 d.

8. Shere Ali and the Koran. To the Editor of the „Daily Telegraph“. In: The Times of India Bd. 41, Nr. 259, v. 25.10.1878, col. 3 e [Nachdruck e. Leserbriefes v. 25.9.1878].

\section{0}

1. Obrazy obyczajowe ze Wschodu, Warszawa, 1880: Nakł. J. Kaufmana, III + 454 pp. [hat nicht vorgelegen, Übers. v. Nr. 264; dt. „Sittenbilder aus dem Orient"].

2. Herat und der europäische Handel. In: Österreichische Monatsschrift für den Orient Nr. 2 (1880), pp. $21-23.5$

3. Az Oroszok és Angolok közti vetélkedés Közép-Ázsiában [dt. „Die Rivalität zwischen den Russen und den Engländern in Zentralasien"]. In: Budapesti Szemle Nr. 46 (1880), pp. $243-278$.

\footnotetext{
${ }^{5}$ Wird in Knüppel (2013, S. 95) erwähnt, nicht aber in Knüppel (2017) aufgeführt.
} 
4. Az oroszok hadviselése Ázsiában [dt. „Die Kriegsführung der Russen in Asien“]. In: Pesti Napló Nr. 93, v. 15.4.1880 (Morgenausgabe), ohne Seitenzahl.

5. Russia's Influence Over the Inhabitants of Central Asia During the Last Ten Years. In: The Journal of the Society of Arts Bd. 28, Nr. 1431, v. 23.4.1889, coll. 475 b-480 b [Abdruck e. Vortrags; anschließende Diskussion ebenda, coll. 480 b-484 b].

6. The Turks of Afghanistan. To the Editor of „The Times of India“. In: The Times of India Bd. 43 N. S., Nr. 143, v. 16.6.1880, coll. 2 e-f.

1. [kurz erwähnt bei Nr. 148] Indiai tündérmesék [dt. „Indische Märchen“], 2. Auflage, Budapest, 1881: Franklin, $362 \mathrm{pp}$. [hat nicht vorgelegen].

2. Merv, die Königin der Welt [Rez. zu: Marvin, Charles: Merv, the Queen of the World, London, 1881]. In: Beilage zur Allgemeinen Zeitung Nr. 76, v. 17.3.1881, coll. 1115 a-b.

\section{2}

1. Die Juden im Orient. In: Der Israelit Jg. 23, Nr. 30, v. 26.7.1882, coll. 654 b-656 b [Auszug aus Nr. 284].

2. A korán-olvasó [dt. „Der Koran-Vorleser“]. In: Vasárnapi Ujság Jg. 29, Nr. 7, v. 12.2.1882, coll. 101 a-102 a [ungar. Fassung von Nr. 388].

3. A magyarok állam-alkotása. Vámbéry „A magyarok eredete“ czimü müvéből [dt. „Die Staatsgründung der Ungarn. Aus Vámbérys Arbeit ,Der Ursprung der Ungarn']. In: Vasárnapi Ujság Jg. 29, Nr. 41, v. 8.10.1882, coll. 654 b-655 b.

\section{3}

1. Ifjukori éveim [dt. „Meine Jugendjahre“]. In: Vasárnapi Ujság Jg. 30, Nr. 46, v. 18.11.1883, coll. 745 a-746 c; 30 (47), v. 25.11.1883, coll. 754 b-758 a.

\section{4}

1. Jelentés a földrajz körében 1883-ban tett munkálatokról [dt. „Bericht über die 1883 geleisteten Arbeiten auf dem Gebiet der Geografie“]. In: Földrajzi Közlemények Bd. 12 (1884), pp. $65-72$.

2. Utazó kalandorok Ázsiában és Európában [dt. „Reisende Abenteurer in Asien und Europa“]. In: Vasárnapi Ujság Jg. 31, Nr. 14, v. 6.4.1884, coll. 214 b-215 b; Nr. 15, v. 13.4.1884, coll. $230 \mathrm{c}-231 \mathrm{c}$.

3. Vambery and the Boundary Comission. In: The Times of India Bd. 47 N. S., Nr. 269, v. 11.11.1884, coll. 6 c-d; Nr. 270, v. 12.11.1884, coll. 5 f-6 a; Nr. 271, v. 13.11.1884, col. 6 a [Vorabdruck v. Nr. 415].

4. Mnenie g. Vamberi o prisoedinenii Merva k našim vladenijam. In: Novoe vremja Nr. 2859 (1884).

> Turkestanskij Sbornik Bd. 359, Sanktpeterburg, 1884, pp. 83-84. 


\section{5}

1. L'Angleterre et la Russie en Asie. In: Le Temps Jg. 25, Nr. 8712, v. 7.3.1885, ohne Seitenzahl [coll. 2 a-b; Übers. v. Nr. 441].

2. Herat - Gate of India. In: Journal of the Royal Society of Arts Bd. 133, Nr. 5346, v. 8.5.1885, p. 432.

3. Herat i jego mieszkańcy [dt. „Herat und seine Bewohner“]. In: Wędrowiec Jg. 23, Nr. 32, v. 6. 8.1885, coll. $382 \mathrm{a}-383 \mathrm{c}$.

4. M. Vambery's Opinion of the Afghan Question. In: Oamaru Mail Jg. 9, Nr. 2560, v. 9.6.1885, col. 3 b sowie in Hawke's Bay Herald Bd. 22, Nr. 7189, v. 15.6.1885, col. 3 c. [auszugsweise Übers. e. Artikels aus Egyetértés].

5. Die Russen und Afghanen. In: Beilage zu Nr. 82 des „Grazer Volksblatt“ vom 12. April 1885, ohne Seitenzahl [Übersetzung eines Artikels aus Egyetértés].

6. Gerat i ego obitateli. In: Novosti Nr. 100 (1885); Nr. 112 (1885).

> Turkestanskij Sbornik Bd. 376, Sanktpeterburg, 1883, pp. 82-84, 86-88.

\section{6}

1. Discours d'ouverture. In: Abrégé du Bulletin de la Société Hongroise de Géographie Bd. 14, pp. 3-11 [frz. Übers. des folgenden Titels].

2. Megnyitó beszéd [dt. „Eröffnungsrede“]. In: Földrajzi Közlemények Jg. 14 (1886), pp. 3-10.

3. Tjurkskie narody. In: Kavkaz Jg. 41, Nr. 132, v. 20.5.1886, coll. 1 a-2 f.

4. Tureckij narod. In: Sovremennye izvestija Nr. 126 (1886) [hat nicht vorgelegen].

5. Zur Charakteristik der staatgründenden [sic] Ungarn. In: Ungarische Revue Bd. 6 (1886), pp. $722-732$.

6. [ohne Titel]. In: Ungarische Revue Bd. 6 (1886), pp. 322-330.

\section{7}

1. Peredviženija i sud'by tjurkskogo naroda. In: Jadrincev, N. M. (Hrsg.): Sibirskij sbornik. Naučno-literaturnoe periodičeskoe izdanie. Priloženie k Vostočnomu Obozreniju 1887, S.-Peterburg, 1887, pp. 206-217 [Übers. v. Kapitel 6 v. Nr. 423].

2. Die Russen in Kerki. In: Allgemeine Zeitung Nr. 165, v. 16.6.1887, coll. 2409 a-b.

3. Russia and England in the East. To the Editor of „The Times of India“. In: The Times of India Bd. 50 N. S., Nr. 236, v. 5.10.1887, col. 4 f [Leserbrief v. 10.9.1887].

4. The Russians and Afghanistan. To the Editor of „The Times of India“. In: The Times of India Bd. 50 N. S., Nr. 172, v. 23.7.1887, col. 5 c [Übers. von „Die Russen in Kerki“ aus der Allgemeinen Zeitung v. 16.6.1887].

5. Die Wirren in Afghanistan. In: Allgemeine Zeitung Nr. 74, v. 15.3.1887, coll. 1073 a-1074 a.

6. Zakaspijskaja železnaja doroga. In: Delo Jg. 20, Bd. 4 (1887), pp. 87-105 [Übers. v. Nr. 494].

7. Zur Chodscha Salih- oder Cham-i-Ab-Frage. In: Allgemeine Zeitung Nr. 114, v. 24.4.1887, coll. $1865 \mathrm{a}-\mathrm{b}$.

8. [ohne Titel]. In: Berliner Börsen-Zeitung Nr. 270 (Morgenausgabe), v. 14.6.1887, coll. 3 c4 a [Übers. v. Nr. 489].

9. [ohne Titel]. In: Berliner Börsen-Zeitung Nr. 364 (Morgenausgabe), v. 7.8.1887, col. 4 b [Übers. v. Nr. 467]. 


\section{8}

1. Ishak Khan. In: The Press (Christchurch) Bd. 45, Nr. 7182, v. 18.10.1888, col. 5 f [gekürzte Übers. e. Artikels aus dem Pester Lloyd].

2. Jelentés az 1887. évi földrajzi munkálatokról [dt. „Bericht über die geografischen Arbeiten des Jahres 1887“]. In: Földrajzi Közlemének Jg. 16 (1888), pp. 89-99.

3. Vajon csakugyan hanyatlásnak indúlt-e Angolország? [dt. „Geht England wirklich dem Verfall entgegen?"] In: Budapesti Szemle Nr. 143 (1888), pp. 270-284.

4. [o. T.]. In: Vorarlberger Landes-Zeitung Nr. 40, v. 18.2.1888, ohne Seitenzahl [Nachdruck e. Leserbriefes an die Deutsche Revue].

\section{9}

1. Discours du président. In: Abrégé du Bulletin de la Société Hongroise de Géographie Jg. 17, pp. 1-9 [frz. Übers. v. Nr. 2 d. laufenden Jahres].

2. Elnöki beszéd [dt. „Rede des Präsidenten“]. In: Földrajzi Közlemények Jg. 17 (1889), pp. $35-43$.

3. Ein ungarischer Volksstamm. In: Ungarische Revue Bd. 9 (1889), pp. 294-296.

1. Concerning the Shah. In: The National Observer Bd. 6, Nr. 147, v. 12.9 .1891 coll. 428 b$429 \mathrm{~b}$.

2. Concerning the Sultan. In: The National Oberserver Bd. 6, Nr. 142, v. 8.8.1891, coll. 298 a299 b.

3. The Magyar Literature of the Last Fifty Years. In: The New Review Bd. 5, Nr. 29 (Oktober 1891), pp. 344-354.

1892

1. The Russian Advance in the Pamirs. In: The New Review Bd. 7, Nr. 40 (September 1892), pp. $262-270$.

2. The Russians on the Pamirs. To the Editor of „The Times of India“. In: The Times of India Bd. 55, N. S. Nr. 260, v. 1.11.1892, col. 5 d [Leserbrief v. 12.10.1892].

1893

1. European Culture and Asiatic Criticism. In: The New Review Bd. 9, Nr. 52 (Oktober 1893), pp. $428-439$.

2. The Struggle for Freedom in Moslem Asia. In: The Literary Digest Bd. 8, Nr. 1, v. 4.11.1893, coll. 4 a-b [auszugsweise Übers. ins Englische v. Nr. 566].

3. Szabadságtörekvések a moszlim Ázsiában [dt. „Freiheitsbestrebungen im moslemischen Asien“]. In: Budapesti Szemle Nr. 214 (1893), pp. 321-338. 
1. Ein Jahr in Persien [Rez. zu: Browne, Edward G.: A Year amongst the Persians. Impressions as to the Life, Character, and Thought of the People of Persia, Received during Twelve Months' Residence in that Country in the Years 1887-8, London, 1893]. In: Beilage zur Allgemeinen Zeitung Nr. 44, v. 22.2.1894, coll. $1 \mathrm{a}-2$ b.

2. Die englische Mission in Kabul. In: Pester Lloyd Jg. 41, Nr. 4 (1894), v. 5.1.1894, ohne Seitenzahl.

3. Die ökonomischen Verhältnisse Centralasiens [Rez. zu: Moser, Henri: L'Irrigation en Asie Centrale. Etude géographique et économique, Paris, 1894]. In: Beilage zur Allgemeinen Zeitung Nr. 59, v. 12.3.1894, coll. 1 a-2 b.

\section{5}

1. Khina és Japán a modern műveltség terén [dt. „China und Japan im Bereich der modernen Bildung“]. In: Budapesti Szemle Nr. 218 (1895), pp. 161-182; Nr. 219 (1895), pp. 349363.

\section{6}

1. Braterstwo ludów. In: Kuryer Lwowski Nr. 287, v. 15.10.1896, coll. 1 c-2 a [dt. „Die Brüderschaft der Völker"; Brief an Delegierten d. Budapester Friedenskongresses].

2. Még egy szó a „Magyarság Keletkezésé“-ről [dt. „Noch ein Wort über die „Entstehung der ungarischen Nation"]. In: Budapesti Szemle Nr. 238 (1896), pp. 285-294.

3. Von der ungarischen Race. In: Gelléri, Moriz (Hrsg.): Aus der Vergangenheit und Gegenwart des tausendjährigen Ungarn, Budapest, 1896, pp. 36-46.

1. Les Turcs d'aujourd'hui et avant quarante ans. I: Réformes Turques depuis quarante ans. In: Mechveret (Supplément français) Bd. 2, Nr. 41, v. 15.8.1897, p. 16; Nr. 43, v. 15.9.1897, p. 8.

2. Über den Ursprung der Magyaren. In: Mittheilungen der kaiserlich-königlichen Geographischen Gesellschaft in Wien XL (1897), pp. 167-186 [am 5.3.1896 in Wien gehaltener Vortrag].

\section{8}

1. Die Chancen des Wettkampfes in Ostasien. In: Die Wage. Eine Wiener Wochenschrift Jg. 1, Nr. 8, v. 19.2.1898, coll. 125 a-126 a.

2. Nyugoti vetélytársak keleti Ázsiában [dt. „Westliche Rivalen in Ostasien“]. In: Budapesti Szemle Nr. 257 (1898), pp. 161-177.

3. Zur Theilung Chinas. In: Die Wage. Eine Wiener Wochenschrift Jg. 1, Nr. 2, v. 8.1.1898, coll. 1 a-2 a. 
1. Russia at Bunder Abbas. To the Editor of „The Times of India“. In: The Times of India Bd. 62 N. S., Nr. 138, v. 12.6.1899, col. 5 c [Leserbrief v. 23.5.1899].

1. Perzsia és a magyarok [dt. „Persien und die Ungarn“]. In: Vasárnapi Ujság Jg. 47, Nr. 46, v. 18.11.1900, coll. 757 a-758 a.

2. Professor Vambéry und die deutsche Sprache. In: Berliner Tageblatt Jg. 29, Nr. 288 (Abend-Ausgabe), v. 9.6.1900, ohne Seitenzahl [Brief v. 7.6.1900].

1. L'avenir de l'Islam. Enquête par Edmond Fazy. In: Questions diplomatiques et coloniales. Revue de politique extérieure, v. 1.8.1901, pp. 147-151.

2. La Perse orientale et le Khorassan d'après un livre récent [Rez. zu: Yate, C.-E.: Khurasan and Sistan, London, 1900]. In: La Géographie. Bulletin de la Société de géographie Bd. 3, Nr. 3, v. 15.3.1901, pp. 165-168.

3. Rußland am Persischen Meerbusen. In: Deutsche Revue Jg. 26 (Dezember 1901), pp. 316329.

4. Unsre [sic] Beziehungen zu China und zur Islamwelt. In: Deutsche Revue Jg. 26 (Februar 1901), pp. 155-177.

5. Visszaemlékezéseim az Angol udvarra [dt. „Meine Erinnerungen an den englischen Hof"]. In: Vasárnapi Ujság Jg. 48, Nr. 5, v. 3.2.1901, coll. 65 a-67 b.

1. Beiträge zur Kenntnis der türkischen Armee [Rez. zu: Schlözer, Leopold v.: I. Ursprung und Entwicklung des alten türkischen Heeres. II. Das türkische Heer im 19. Jahrhundert, Berlin, 1901]. In: Deutsche Revue Jg. 27 (Januar 1902), pp. 124-125.

2. „A Friend of Britain“. A Celebrated Foreigner's Views. In: Wanganui Herald Bd. 36, Nr. 10594, v. 17.3.1902, coll. 12 g-h [Brief an neuseeländ. Privatperson v. 24.1.1902; Nachdruck in div. neuseeländ. u. austral. Zeitungen].

3. Jelentés a Lukács Krisztina-féle nyilt pályázatról [dt. „Bericht über die offene Bewerbung von Krisztina Lukács“]. In: Akadémiai Értesitő Bd. 13, Nr. 6-7 (Juni-Juli 1902) pp. 398403.

4. Oroszország a Perzsa-Tengeröbölben [dt. „Russland am Persischen Golf“]. In: Budapesti Szemle Nr. 312 (1902), pp. 321-338.

5. [ohne Titel]. In: Achmet Dsevdet efendi és Vámbéry Ármin tt. Előszava Evlia Cselebi Sziáhetnáme czímü munkája VI. Kötetéhez. In: Akadémiai Értesitő Bd. 13, Nr. 2, v. 15.2.1902, pp. 102-104, hier pp. 103-104 [enthält die ungarische Übers. d. ursprünglich osmanischen Geleitwortes zu der von Ahmed Cevdet besorgten Ausgabe des 6. Bandes von Evliya Çelebis Reisebeschreibung (İstanbul, 1318/1902)]. 
1. Die Lage in Macedonien. In: Deutsche Revue Jg. 28 (Mai 1903), pp. 222-227.

2. Der Sturm auf Englands Machtstellung und die englisch-deutschen Beziehungen in Asien. In: Deutsche Revue Jg. 28 (März 1903), pp. 153-168; (April 1903), pp. 295-318.

\section{5}

1. [kurz erwähnt bei Nr. 394] Vámbéry Ármin utazásai Ázsiában [dt. „Ármin Vámbérys Reisen in Asien"], 2. Auflage, Budapest: Athenaeum, 1905, 224 pp.

2. Invloed der russische nederlagen op de aziatische mohammedanen [dt. „Der Einfluss der russischen Niederlage auf die asiatischen Mohammedaner"]. In: Wetenschappelijke bladen Teil 3 (1905), pp. 161-175 [Übers. d. Artikels aus der Deutschen Revue vom April 1905].

3. Islam and the War. Letter from M. Vambery to the Editor of „The Times of India“. In: The Times of India Bd. 58, Nr. 129, v. 22.5.1905, col. 7 d [Leserbrief v. 1.5.1905].

4. Japan's Triumph. Islam and the War. In: The Times of India Bd. 68, Nr. 83, 7.4.1905, coll. 7 e-f.

5. Nyílt levél Radó Vilmos tanár úrhoz (Mint előszó a második kiadáshoz) [dt. „Offener Brief an Herrn Lehrer Vilmos Radó (als Vorwort zur ersten Auflage)“]. In: Radó, Vilmos (Hrsg.): Vámbéry Ármin utazásai Ázsiában, 2. Auflage, Budapest, 1905, pp. 1-2 [Vorwort zur ersten Auflage vom Mai 1893].

6. Professor Vambery über das Reiseprojekt Sven Hedins. In: Neue Freie Presse (Abendblatt) Nr. 14789, v. 24.10.1905, coll. 3 c-4 a.

7. Die Rückwirkung der russischen Niederlage auf die Islamwelt in Asien. In: Deutsche Revue Jg. 30 (April 1905), pp. 208-218.

\section{6}

1. Tatárok az alkotmányban [dt. „Tataren in der Verfassung“]. In: Vasárnapi Ujság Jg. 53, Nr. 19, v. 13.5.1906, col. $307 \mathrm{c}$.

\section{7}

1. Pătuvane po Centralna Azija [dt. „Reise durch Zentralasien“]. Sofija, 1907 [nach anderen Informationen: 1910]: St. Atanasov, 191 pp. [lediglich undatiertes Titelblatt lag vor].

2. Das englisch-russische Abkommen. In: Neue Freie Presse Nr. 15455, v. 1.9.1907, coll. 5 c$6 \mathrm{c}$.

3. Die englisch-russische Vereinbarung. In: Deutsche Revue Bd. 32 (Mai 1907), pp. 206-220.

4. Magyarok és tatárok [dt. „Ungarn und Tataren“] In: Vasárnapi Ujság Jg. 54, Nr. 23, v. 9.6.1907, coll. $465 \mathrm{c}-466$ a.

5. Om den nye persiske Schahen [dt. „Über den neuen persischen Schah“]. In: Hufvudstadsbladet (Helsingfors/Helsinki) Jg. 43, Nr. 14, v. 15.1.1907, coll. 6 b-d.

6. A panislamismus [dt. „Der Panislamismus“]. In: Budapesti Szemle Nr. 362 (1907), pp. $225-$ 241.

7. A perzsa alkotmány atyja [dt. „Der Vater der persischen Verfassung“]. In: Vasárnapi Ujság Jg. 54, Nr. 14, v. 7.4.1907, coll. $281 \mathrm{a}-$ b. 
8. A Tatárok kultur-törekvései [dt. „Die kulturellen Bestrebungen der Tataren“]. In: Budapesti Szemle Nr. 369 (1907), pp. 348-376.

9. Het vergelijk tusschen Groot-Brittanje en Rusland [dt. „Die Einigung zwischen Großbritannien und Russland“"]. In: Wetenschappelijke bladen 4. Teil (1907), pp. 59-80.

\section{8}

1. L'Eveil des Femmes Mahométanes. In: Les Documents du progrès. Revue internationale Jg. 2 (Janvier 1908), pp. 316-321.

2. Nouvelles tendances religieuses. L'Islam en marche vers la civilisation. In: Les Documents du progrès. Revue internationale Jg. 2 (April 1908), pp. 84-87.

3. Die türkische „Revolution“. In: Allgemeine Zeitung Nr. 21, v. 22.8.1908, coll. 432 b-434 a.

4. Über den Staatsstreich in Persien. In: Neue Freie Presse (Morgenblatt) Nr. 15737, v. 13.6.1908, coll. 5 b-6 a.

1. Az alkotmányos Törökország jövöje [dt. „Die Zukunft der konstitutionellen Türkei“]. In: Budapesti Szemle Nr. 387 (1909), pp. 356-371.

2. Das erste und zweite türkische Parlament. In: Allgemeine Zeitung Nr. 2, v. 9.1.1909, coll. $29 \mathrm{a}-30 \mathrm{~b}$.

3. Das erste und zweite türkische Parlament. In: Bozner Zeitung (Südtiroler Tagblatt) Jg. 69, Nr. 9, v. 13.1.1908, ohne Seitenzahl [coll. 1 a-c; Auszug aus dem vorangegangenen Artikel].

4. Die Revolution und Persien und die Frage der Intervention. In: Neue Freie Presse (Morgenblatt) Nr. 16125, v. 14.7.1909, coll. 2 a-c.

5. Die russische Intervention in Persien. In: Neue Freie Presse (Abendblatt) Nr. 15943, v. 9.1.1909, coll. $1 \mathrm{c}-2 \mathrm{~b}$.

6. Rysslands planer mot Persien. Ett märkligt uttalande [dt. „Russlands Pläne gegen Persien. Eine bemerkenswerte Äußerung"]. In Hufvudstadsbladet (Helsingfors/Helsinki) Nr. 17, v. 19.9.1909, coll. 6 f-g [auszugsweise Übers. d. Artikels aus der Neuen Freien Presse v. 9.1.1909].

7. Vambéry's persoonlijke herinneringen omtrent Abdoel Hamid II [dt. „Vámbérys persönliche Erinnerungen an Abdulhamid II.“]. In: Wetenschappelijke bladen 3. Teil (1909), pp. 161-189 [gekürzte Übers. v. Nr. 721 und 722].

\section{0}

1. Mustaqbil-i Islām [dt. „Die Zukunft des Islams“"]. Āgrā, 1910: Matbā'-i mufīd-i ‘ām, XII + 195 pp. [Urdu-Übersetzung von Kapitel 3 v. Nr. 686, hat nicht vorgelegen].

2. Meine Erinnerungen an Dr. Herzl. In: Die Welt (Wien) Jg. 14, Nr. 20, v. 20.5.1910, coll. $478 \mathrm{~b}-479 \mathrm{~b}$.

3. Tulteng-e nálunk a politika? [dt. „Gibt es bei uns zu viel Politik?“] In: Vasárnapi Ujság Jg. 57, Nr. 4, v. 23.1.1910, coll. 81 c-82 a. 
1. Englands Kolonien. In: Neue Freie Presse (Morgenblatt) Nr. 16856, v. 27.7.1911, coll. 20 c$21 \mathrm{c}$.

2. Uba wä qalġa süzläre xaqïnda [dt. „Über die Wörter uba und qalġa“]. In: Šura (Orenburg) Jg. 4, Nr. 3 (1911), coll. 85 b-86 a.

\section{2}

1. Der Dank des 80jährigen Vambery. In: Neues Wiener Tagblatt (Tages-Ausgabe) Nr. 80, v. 22.3.1912, col. 13 b.

2. Elnöki megnyitó. A negyvenéves jubiláris közgyülésen elmondta: Vámbéry Ármin [dt. „Die Eröffnungsrede des Präsidenten. Es sprach auf der Festveranstaltung zum vierzigsten Jahrestag: Ármin Vámbéry]. In: Földrajzi Közlemények Bd. 40 (1912), pp. 21-26.

3. Kul'turnoe dviženie sredi russkich tatar. In: I. Gol'dciger [= Goldziher]: Lekcii ob islame, Sanktpeterburg, 1912, pp. 276-301 [Übersetzung von Nr. 706].

4. Oroszország és Anglia Perzsiában [dt. „Russland und England in Persien“]. In: Budapesti Szemle Nr. 432 (1912), pp. 359-369.

5. Perzsia, Tripolis, Marokko - közeledés muzulmánok s buddhisták közt [dt. „Persien, Tripolis, Marokko - Annäherung zwischen Muslimen und Buddhisten"]. In: Budapesti Szemle Nr. 425 (1912), pp. 184-197.

6. [ohne Titel]. In: Neues Wiener Journal Nr. 6629, v. 7.4.1912, col. 15 b.

\section{3}

1. Abdul Hamidról [dt. „Über Abdulhamid“]. In: Vasárnapi Ujság Jg. 60, Nr. 38, v. 21.9.1913, coll. $750 \mathrm{~b}-\mathrm{c}$.

2. A mohammedánok ébredése Ázsiában [dt. „Das Erwachen der Mohammedaner in Asien“]. In: Turán Jg. 1, Nr. 2 (1913), pp. 61-68.

3. Törökország összeomlása és az iszlámság [dt. „Der Zusammenbruch der Türkei und der Islam“]. In: Budapesti Szemle Nr. 437 (1913), pp. 338-355.

\section{4}

1. Moja žizn', Moskva, 1914: Nauka, VIII + 408 pp. [Übersetzung von Nr. 670].

2. Briefe an Sidney Whitman v. 12.11.1912, 14.12.1912, 30.12.1912, 1.1.1913, 6.1.1913, 11.2.1913, 14.2.1913, 20.2.1913, 21.2.1913 und 28.4.1913. In: Whitman, Sidney: Turkish Memories, New York: Chas. Scribner's Sons, 1914, pp. 284-293.

3. Egy tatár emlékirataiból [dt. „Aus den Erinnerungen eines Tataren“]. In: Huszadik Század 15 (29) (1914), pp. 1-22.

\section{$1916 / 1917$}

1. Ämir Teymur. Mäşhur Macar müsteşriqlärindän professor Vamberi’nin „Tarixi Buxara“ nam äsärindän iqtibas edilmiştir. Baku 1916/1917: Näşriyyati Bäradärani Orucov, 159 pp. [dt. 
„Amir Timur“; Erscheinungsdatum laut Buchdeckel: 1917; laut erster Druckseite: 1916, dort auch mit parallelem russischen Titel Ėmir-Tejmur. Sočinenie izvestnogo vengerskogo professora Germana Vanmberi (sic)].

\section{4}

1. Toldot Arminyus Vamberi: u-mas'otay be-artsot ha-mizrah, Frankfurt a. M., 1924: Hotsa'at „Omanut“, 68 pp. [gekürzte Übers. v. Nr. 407 ins Hebräische, hat nicht vorgelegen].

\section{1}

1. Sketches of Central Asia: Additional Chapters on My Travels, Adventures and on the Ethnology of Central Asia, Taipei, 1971: Ch'eng Wen, VIII + 444 pp. [Nachdruck v. Nr. 103, hat nicht vorgelegen].

1. Buxoro yoxud Movarounnahr tarixi [dt. „Buchara oder die Geschichte Transoxaniens"], Toşkent, 1990: Ghafur Ghulom [hat nicht vorgelegen].

1. Ämir Teymur [dt. „Amir Timur“]. Mäşhur macar professorunun äsäri, Bak1, 1991: Azärbayan Dövlät Kitab Palatası, 82 pp. [Transkription des Bandes 1916/1917 in die kyrillische Schrift; hat nicht vorgelegen].

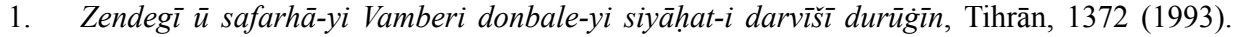
[neu-pers. Übers. v. Nr. 514].

1996

1. Probuždenie tatar. In: Tatarstan 11 (1996), pp. $22-30$ [Übers. v. Nr. 676].

\section{1}

1. Tārīh-i Buhārāa : az kuhantarīn rūzgārān tā kunūn, Tihrān, 1380 (2001) [hat nicht vorlegen]. 
1. [ohne Titel]. In: Kahraman, Seyit Ali/Dağl1, Yücel (Hrsg.): Evliyâ Çelebi b. Derviş Mehemmed Zıllî. Evliyâ Çelebi Seyahatnamesi VI. Kitap. Topkapı Sarayı Kütüphanesi Revan 1457 Numaralı Yazmanın Transkripsiyonu - Dizini, İstanbul, 2002, p. IX [Transkription eines Geleitwortes, das für die 1902 von Ahmed Cevdet besorgte Ausgabe [İstanbul, 1318 (1902)] des 6. Bandes von Çelebis Reisebeschreibung verfasst wurde].

\section{3}

1. A magyarok keletkezése és gyarapodása [dt. „Die Genese und Ausbreitung der Ungarn“], Dunaszerdahely: Lilium Aurum, 393 pp. [hat nicht vorgelegen].

2006

1. Putešestvie po Srednej Azii. Orta Aziyaġa sayaxat (Biblioteka kazachskoj ètnografii), Pavlodar, 2006: Ėko, 315 pp. [hat nicht vorgelegen].

2., ergänzte Auflage: Astana, 2007: Altïn kitap [hat nicht vorgelegen].

2. Orta Aziyag̉a sayaxat; Buxar xandïgï; Orta Aziyanīñ iški žänä sïrtqï sayasi qarïm-qatïnastarï [dt. „Reise nach Zentralasien; das Khanat von Buchara; die inneren und äußeren Beziehungen Mittelasien“]. In: Tüläuova, A. Ž. (Hrsg., Übers.): Tarix - adamzat aqül-oyïnïn qazïnasï Bd. 6, Astana, 2006, pp. 248-260 [hat nicht vorgelegen].

1. From the Memoirs of a Tartar. In: Shofar 25 (3), pp. 22-31 [auszugsweise Übers. d. dritten Eintrags des Jahres 1914 der vorliegenden Bibliografie durch David Mandler].

2. Arminius Vambéry: How I Decided to Travel to Europe, and Why I Wrote My Memoirs. Translated by David Mandler. In: Shofar 25 (3), pp. 16-21 [Übers. von Nr. 755 durch David Mandler].

\section{8}

1. Putešestvie po Srednej Azii. Taškent, 2008: Institut istorii narodov Srednej Azii imeni Machpirat, $409 \mathrm{pp}$. [hat nicht vorgelegen].

2. Siyāhat-i darvīšl durūg̀̄̄n dar hāanāt-i Āsiyā-yi miyāne. Tihrān, 1387 (2008) [hat nicht vorgelegen; Neudruck v. Nr. 759].

\section{3}

1. Ämir Teymur [dt. „Amir Timur“]. Äräb älifbasından transfoneliterasiya ed., lüğätin müäl. T. Häsänzadä; red. F. Äläkbärli. Bak1, 2013: Elm vä tähsil, 131 pp. [Transkription des Bandes 1916/1917 in die Lateinschrift; hat nicht vorgelegen]. 
1. Siyāhat ū māğerāhāa-yi man dar Irān, o. O. o. J. [Übers. v. Nr. 85 durch Khosrow Sinai, hat nicht vorgelegen].

\section{Bio-Bibliografisches}

\section{4}

1. Dalmady, Győző: Vámbéry Árminnak [dt. „Für Ármin Vámbéry“]. In: Vasárnapi Ujság Jg. 11, Nr. 50, v. 11.12.1864, col. 538 a [Vámbéry gewidmetes Gedicht].

2. Malte-Brun, V.: Voyage de M. Vambéry à Khiva, à Boukhara et a Samarcande. In: Nouvelles annales des voyages Bd. 4 (1864), pp. 353-369.

3. [ohne Vf.]: Britische Gründlichkeit. In: Grazer Zeitung Nr. 224, v. 1.10.1864, coll. 1 a-c.

4. [ohne Vf.]: Forschungsreisen in Zentral-Asien. In: Grazer Zeitung Nr. 151, v. 6.7.1864, coll. $595 \mathrm{a}-\mathrm{b}$.

5. [ohne Vf.]: Eine Reise in Zentral-Asien. In: Vereinigte Laibacher Zeitung Nr. 152, v. 7.7.1864, coll. 2 a-3 a.

6. [ohne Vf.]: Interessanter Reisebericht eines Ungarn. In: Bothe für Tirol und Vorarlberg Jg. 50, Nr. 152, v. 7.7.1864, coll. 643 b-c.

7. [ohne Vf.]: Voyage dans l'Asie centrale. In: La Science pittoresque Nr. 10, v. 8.7.1864, p. 120.

8. [ohne Vf.]: Vámbéry Ármin. In: Vasárnapi Ujság Jg. 11, Nr. 49, v. 4.12.1864, coll. 525 a-526 b.

\section{5}

1. Major, Béla: Látogatás a persa shachnál. Vámbéry Armin keleti utazásából [dt. „Besuch beim persischen Schah. Von der Orientreise Ármin Vámbérys"]. In: Családi Kör Nr. 7 (1865), coll. 153-156.

2. [ohne Vf.]: Herman Vambery ja hänen matkustuksensa Keski-Aasiassa [dt. „Hermann Vámbéry und seine Reise in Mittelasien"]. In: Maiden Ja Merian Takaa Nr. 15 (1865), v. 1.8.1865, coll. 115 a-117 a; Nr. 17 (1865), v. 1.9.1865, coll. 132 b-135 a.

3. [ohne Vf.]: Hermann Vambery's Reisen in Central-Asien. In: Bothe für Tirol und Vorarlberg Jg. 51, Nr. 4, v. 5.1.1865, coll. 15 a-b; Nr. 6, v. 9.1.1865, coll. 22 b-23 a; Nr. 8, v. 11.1.1865, coll. $31 \mathrm{a}-\mathrm{c}$; Nr. 9, v. 12.1.1865, coll. 35 b-c [Nachdruck v. Nr. 4.1.15].

4. [ohne Vf.]: Podróż p. Vambery do środkowej Azji [dt. „Die Reise des Herrn Vámbéry nach Mittelasien“]. In: Gazeta Polska Nr. 21 (1865), v. 27.1.1865, coll. 3 b-d.

5. [ohne Vf.]: Die Russen in Mittelasien. In: Klagenfurter Zeitung Nr. 139, v. 20.6.1865, coll. $1 \mathrm{~b}-2 \mathrm{a}$; Nr. 141, v. 22.6.1865, coll. 1 b-2 a.

6. [ohne Vf.]: Vámbéry Khivában [dt. „Vámbéry in Chiwa“]. In: Vasárnapi Ujság Jg. 12, Nr. 53, v. 31.12.1865, coll. $676 \mathrm{a}-\mathrm{c}$.

\section{7}

1. [ohne Vf.]: Hermann Vambery som Dervisch [dt. „Hermann Vámbéry als Derwisch“]. In: Skandinavisk Folkemagazin. Et Billedblad for alle Staender Nr. 9, v. 3.3.1867, coll. 129-132. 
2. [ohne Vf.]: Po povodu soč. Vamberi Soperničestvo Rossii i Anglii v Sr. Azii. In: Moskva, v. 16.11.1867 [Kommentar zu Nr. 96].

> Turkestanskij Sbornik 1867 Bd. 1, Sanktpeterburg, 1868, pp. 291-293.

\section{8}

1. [ohne Vf.]: Arminius Vambéry, the Hungarian Orientalist. In: American Phrenological Journal Bd. 47, Nr. 3, pp. 93-95.

2. [ohne Vf.]: Chiva i Buchara (po Vamberi). In: Zapiski dlja čtenija Juli- August (1868), pp. $273-282$.

3. [ohne Vf.]: Hermann Vambéry. In: Izraelita Jg. 3, Nr. 7, v. 14.2.1868, coll. 51 a-52 a.

4. [ohne Vf.]: Schetsen Uit Midden-Azië [dt. „Skizzen aus Mittelasien“]. In: De Aarde en haar Volken. Geillustreerd Volksboek, Haarlem, 1868, pp. 297-323.

\section{9}

1. St. v. R.: Ausblicke über den Zaun hinaus. 5. Von den mohamedanischen Schulen. In: Schweizerische Lehrer-Zeitung Nr. 37, v. 11.9.1869, pp. 291-293.

2. [ohne Vf.], [ohne Titel]. In: Den Norske Rigstidende Jg. 55, Nr. 69, v. 12.4.1869, coll. 149 c$150 \mathrm{a}$.

1. [ohne Vf.]: Po povodu stat'i Vambéri: „Rossija i chanstvo Chiva“. In: Birževye Vedomosti Nr. 49 (1870).

> Turkestanskij Sbornik 1870 Bd. 41, Sanktpeterburg, 1871, pp. 199-200.

2. [ohne Vf.]: Po povodu stat'i Vambéri: „Prekraščenie pograničnych sporov meždu Bucharoj i Afganistanom“. In: Birževye Vedomosti Nr. 102 (1870).

> Turkestanskij Sbornik 1870 Bd. 41, Sanktpeterburg, 1871, p. 201.

\section{1}

1. [ohne Vf.]: Russia and England in Asia. In: New-York Tribune Bd. 30, Nr. 9299, v. 25.1.1871, coll. $2 \mathrm{a}-\mathrm{b}$.

\section{3}

1. [ohne Vf.]: Vambéry als Russenfreund. In: Deutsche Zeitung Nr. 711 (Abendblatt), v. 24.12.1873, coll. 2 b-c [zitiert ausführlich Art. aus d. Norddeutschen Allg. Ztg.].

2. [ohne Vf.]: Po povodu sočinenija Vamberi: „Istorija Bochary“. In: Birževye Vedomosti Nr. $142(1873)$.

> Turkestanskij Sbornik Bd. 72, Sanktpeterburg, 1873, pp. 95-96. 
1. ...i...: Vambery's Reisen. In: Die Presse 179, v. 2.7.1874, coll. 8 c-9 a.

2. Grigor'ev, V. V.: Ešče neskol'ko slov po delu o Vamberi. In: Russkij Mir Nr. 45 (1874) [Antwort auf den Leserbrief E. Schuylers in Nr. 37 der gleichen Zeitung]. $>$ Turkestanskij Sbornik Bd. 75, Sanktpeterburg, 1873, pp. 188-190.

3. Grigor'ev, V. V.: O neleposti predloženija, budto Vamberi ne ezdil po Srednej Azii. In: Russkij Mir Nr. 26 (1874).

> Turkestanskij Sbornik Bd. 75, Sanktpeterburg, 1873, pp. 181-185.

4. Skajler, Evgenij [= Schuyler, Eugene]: Pis'mo v redakciju. In Russkij Mir Nr. 37 (1874) [Reaktion auf den Artikel Grigor'evs in Nr. 26 der gleichen Zeitung].

> Turkestanskij Sbornik Bd. 75, Sanktpeterburg, 1873, pp. 186-187.

5. [ohne Vf.]: Zapozdalaja stat'ja Vamberi. In: Birževye Vedomosti Nr. 58, v. 1.3.1874.

> Turkestanskij Sbornik Bd. 75, Sanktpeterburg, 1873, pp. 196-198.

1876

1. [ohne Vf.], [ohne Titel]. In: Das Museum. Belletristisches Beiblatt zur Neuen Frankfurter Presse Nr. 77, v. 31.3.1876, ohne Seitenzahl.

1. [ohne Vf.]: Ignatieff und Midhat Pascha. In: Das Vaterland Nr. 87, v. 30.3.1877, col. 3 a.

2. [ohne Vf.]: Ist Midhat Pascha ein Jude oder ist er es nicht? In: Neue Tiroler Stimmen Nr. 74, v. 31.3.1877, ohne Seitenzahl.

3. [ohne Vf.]: Politische Nachrichten. In Berliner Börsen-Zeitung Nr. 521 (Morgen-Ausgabe), v. 7.11.1877, ohne Seitenzahl [enthält lange Zitate aus Nr. 285].

1. Medvedev, P. P.: Nečajannoe moe znakomstvo s A. Vamberi (II. Priloženie k protokolu zasedanija Soveta 24 oktjabrja). In: Izvestija i učenye zapiski Imperatorskogo Kazanskogo universiteta Jg. 46 (Januar/Februar 1879), pp. 105-108.

\section{0}

1. [ohne Vf.]: Russia's Influence in Central Asia. In: The Times of India Bd. 43 N. S., Nr. 114, v. 13.5.1880, coll. $3 \mathrm{f}-\mathrm{g}$.

\section{2}

1. [ohne Vf.]: Herman Vambery. In: Uleåborgs Tidning (Uleåborg/Oulu) Nr. 8, v. 23.2.1882, ohne Seitenzahl [Nachdruck in div. finnlandschwedischen Zeitungen]. 
2. [ohne Vf.]: Vamberi o russkom dviženii v Central'noj Azii. In: Kavkaz Jg. 37, Nr. 335, v. 18.12.1882, coll. 2 b-d.

\section{3}

1. Kuuleks: Fennomanerne och Vámbéry [dt. „Die Finnen und Vámbéry“]. In: Helsingfors Nr. 6, v. 9.1.1883, coll. 6 a-c.

2. [ohne Vf.]: Das Vorrücken der Russen in Central-Asien. In: Beilage zu Nr. 18 des „Grazer Volksblatt", v. 24.1.1883, ohne Seitenzahl.

3. [ohne Vf.]: The Russian Movement in Central Asia. In: Timaru Herald Bd. 38, Nr. 2612, v. 5.2.1883, coll. $5 \mathrm{c}-\mathrm{d}$.

4. [ohne Vf.]: Vámbéry mint Közép-Ázsiai utazó [dt. „Vámbéry als Zentralasienreisender“]. In: Vasárnapi Ujság Jg. 30, Nr. 48, v. 2.12.1883, coll. 771 c-774 c.

\section{4}

1. J. D.: Un derviche hongrois. In: La Revue Politique et Littéraire Jg. 7, Nr. 14, v. 5.4.1884, pp. $442-443$.

2. Zimmern, Helena: Vambéry. In: Lelie- en rozeknoppen. Weekblad voor meisjes Jg. 2 (1883-1884), Nr. 40, v. 20.2.1884, pp. 316-317; Nr. 41, v. 27.2.1884, pp. 324-325.

3. [ohne Vf.]: Arminius Vambéry. In: All the Year Round Bd. 33, Nr. 804, v. 26.4.1884, coll. 534 a-540 a.

4. [ohne Vf.]: Engelsche Kroniek [dt. „Englische Chronik“]. Arminius Vambéry. In: Algemeen Handelsblad Nr. 16981, v. 2.4.1884, coll. 1a-b [gleichzeitig kurze Besprechung v. Nr. 407].

\section{5}

1. [ohne Vf.]: L'Afghanistan. Une entrevue avec M. Arnim Vambéry à Pesth. In: Le Matin. Derniers télégrammes de la nuit Nr. 419, v. 19.4.1885, col. 1 e.

2. [ohne Vf.]: Der Hahn des Hodscha. In: (Neuigkeits-) Welt-Blatt Nr. 250, v. 31.10.1885, ohne Seitenzahl.

3. [ohne Vf.]: Professor Vambery on Herat. In: The Argus (Melbourne) Nr. 12168, v. 23.6.1885, coll. $9 \mathrm{f}-\mathrm{h}$.

4. [ohne Vf.]: Professor Vambery on Russia. In: Nelson Evening Mail Bd. 20, Nr. 151, v. 29.6.1885, coll. 4 b-c.

5. [ohne Vf.]: Professori H. Wambery'in arweluita [dt. „Professor Vámbérys Meinung"]. In: Kaiku. Sanomia Oulun kaupungista ja läänistä Nr. 35 (1885), v. 2.5.1885, ohne Seitenzahl.

6. [ohne Vf.]: To the Address of M. Vambery. In: Nelson Evening Mail Bd. 20, Nr. 76, v. 1.4.1885, coll. $4 \mathrm{a}-\mathrm{b}$ [Nachdruck e. pseudonymen offenen Briefes an Vámbéry aus der Pioneer Mail v. 18.2.1885].

7. [ohne Vf.]: Wonderful Adventures of Arminius Vambery. In: New Zealand Herald Literary Supplement Bd. 22, Nr. 7371, v. 4.7.1885, col. 4 d. 
1886

1. Cs. L.: Vámbéry rehabilitatiója [dt. „Vámbérys Rehabilitation“]. In: Földrajzi Közlemények Jg. 14 (1886), pp. 455-456.

\section{8}

1. [ohne Vf.]: Ungraren Vambery i Konstantinopel [dt. „Der Ungar Vámbéry in Konstantinopel“]. In: Finland Nr. 239, v. 12.10.1888, ohne Seitenzahl.

\section{9}

1. V-s: Aus Ungarn. In: Deutsches Volksblatt (Abend-Ausgabe) Nr. 139, v. 24.5.1889, coll. 2 a$2 \mathrm{~b}$.

2. [ohne Vf.]: Die Ansichten des Sultans. In: Bregenzer Tagblatt Nr. 1141, v. 26.10.1889, coll. $1 \mathrm{~b}-1 \mathrm{c}$.

\section{2}

1. B. H.: Vámbéry tatárja [dt. „Vámbérys Tatare“]. In: Szabadság Jg. 12, Nr. 62, v. 24.5.1892.

2. [ohne Vf.]: Magjarski učenjaci „svjetskoga glasa“. (Prilog k „kulturnoj povjesti“) [dt. „Ungarische Gelehrte ,von Weltruf". Ein Beitrag zur ,Kulturgeschichte“"]. In: Narod Nr. 99, v. 20.12.1892, coll. 2 b.

\section{3}

1. [ohne Vf.]: Professor Arminius Vambery. In: The Leader (Melbourne) Nr. 1930, v. 7.1.1893, coll. $32 \mathrm{c}-\mathrm{e}$.

\section{7}

1. Roche, Paul: La révolte des Indes et le reveil du panislamisme. In: Le Gaulois Jg. 31, Nr. 5797, v. 25.9.1897, coll. 2 c-d.

2. [ohne Vf.]: Novye fakty, podryvajuščie vernost' pokazanij g. Vamberi. In: Katkov, M. N.: Sobranie peredovych statej Moskovskich vedomostej. 1873 god, Moskva, 1897, coll. 867 a868 b [Nachdruck e. Artikels aus den Moskovskie vedomosti v. 29.11.1873].

3. [ohne Vf.]: Peremena vzgljadov g. Vamberi na sredneazijatskij vopros. In: Katkov, M. N.: Sobranie peredovych statej Moskovskich vedomostej. 1873 god, Moskva, 1897, coll. 716 a718 b [Nachdruck e. Artikels aus den Moskovskie vedomosti v. 28.9.1873].

4. [ohne Vf.]: Putešestvie Vamberi po Srednej Azii. In: Katkov, M. N.: Sobranie peredovych statej Moskovskich vedomostej. 1874 god, Moskva, 1897, coll. 40 a-42 a [Nachdruck e. Artikels aus den Moskovskie vedomosti v. 14.1.1874]. 
1. [ohne Vf.]: Ein Hofjude. In: Staatsbürger-Zeitung Jg. 37, Nr. 147 (Morgen-Ausgabe), v. 28.3.1901.

1. [ohne Vf.]: Hermann Vambery. Zu seinem heutigen Jubeltage. In: Neues Wiener Journal Nr. 3018, v. 20.3.1902, coll. 4 a-b.

\section{4}

1. [ohne Vf.]: Championed a Savant. How King Edward Befriended Professor Vambery. In: The Washington Post Nr. 10228, v. 12.6.1904, col. B4 h.

\section{6}

1. [ohne Vf.]: The New Era in Persia. Chat with Professor Vambery. In: The Times of India Bd. 69, Nr. 270, v. 12.11.1906, col. 8 e.

\section{7}

1. [ohne Vf.]: An Interview with Vambery. In: The Jewish Herald (Melbourne) Bd. 28, Nr. 88, v. 15.11.1907, coll. $406 \mathrm{c}-407$ a.

2. [ohne Vf.]: Persia Yearns for Conquest. In: Los Angeles Times Jg. 26, v. 21.9.1907, col. 3 c.

3. [ohne Vf.]: Prof. Vamberys Hofratswürde. In: Allgemeine jüdische Rundschau Nr. 37, v. 25.10.1907, coll. $3 \mathrm{a}-\mathrm{b}$.

4. [ohne Vf.]: Prof. Vambery on Zionism. Noted Hungarian Discourages Emigration en Masse to Palestine. In: The Washington Post Nr. 11399, v. 25.8.1907, col. 12 b.

5. [ohne Vf.]: Vambery on Zionism. He Thinks Time is not yet Ripe for Colonization. In: New-York Tribune Bd. 67, Nr. 22190, v. 18.8.1907, col. 7 c.

\section{8}

1. [ohne Vf.]: Arminius Vambery. Scholar, Traveller, Diplomatist and Friend of King Edward. In: The Australian Star Extra Special Nr. 6304, v. 25.1.1908, col. 5 g.

2. [ohne Vf.]: Une interview avec M. Vambery (Dépêche de notre correspondant particulier). In: Le Temps Nr. 17325, v. 1.12.1908, ohne Seitenzahl.

3. [ohne Vf.]: Shah May Withdraw. In: The Washington Post Nr. 11672, v. 24.5.1908, coll. $14 \mathrm{a}-\mathrm{b}$. 
1. [ohne Vf.]: Professor Vambery. Message to Australia. In: The Herald (Melbourne) Nr. 10631, v. 25.11.1909, col. 7 a.

2. [ohne Vf.]: Eine Unterredung mit Vambery. In: Agramer Zeitung Nr. 308, v. 23.12.1908, coll. $3 \mathrm{a}-\mathrm{b}$.

\section{0}

1. -a -ly: Vámbéry Ármin. In: Vasárnapi Ujság Jg. 57, Nr. 42, v. 16.10.1910, coll. 861 a-862 b [mit Fotografien v. Vámbéry, auch auf p. 863].

2. Ramsay, Sir William M.: An Interview with Vambery. The Young Turks and Their Needs. England and Germany: a Comparison. In: The Manchester Guardian Nr. 19898, v. 18.5.1910, coll. $6 \mathrm{f}-\mathrm{g}$.

\section{1}

1. Mbch.: Vengerskij prorok. In: V mire musul'manstva Nr. 33, v. 2. (15.) 12.1911, coll. 1 b-d.

2. [ohne Vf.]: Professor Vambery gegen den Islam. In: Neues Wiener Journal Nr. 6442, v. 28.9.1911, col. 9 b.

\section{2}

1. Eşref Edip: Vambery kimdir. In: Sebilürreşad Bd. 1 (8) Nr. 5 (187), v. 22 Mart 1328 (1912), p. 89.

2. Hornstein, Ferdinand v.: Hermann Vambéry als Erzähler (Anläßlich seines achtzigsten Geburtstagsfestes). In: Neue Freie Presse (Morgenblatt) Nr. 17090, v. 21.3.1912, coll. 1 a-3 b.

3. Mn.: Hermann Vambery. In: Postimees (Tartu) Nr. 62, v. 28.3.1912, ohne Seitenzahl.

4. [ohne Vf.]: Aus den Erinnerungen Professor Vamberys. Zum achtzigsten Geburtstag des Gelehrten. In: Neues Wiener Journal Nr. 6609, v. 17.3.1912, col. 6 a.

5. [ohne Vf.]: Über Ursprung und Landnahme der Magyaren. In: Reichenberger Zeitung Nr. 35, v. 3.10.1912, coll. 5 d-6 a.

6. [ohne Vf.]: Writes and Speaks Twenty Languages. Prof. Vambery is World's Famous Orientalist. In: Boston Daily Globe Jg. 82, Nr. 126, v. 3.11.1912, col. 45 c.

\section{3}

1. -a -ly: Vámbéry a Dunaparton [dt. „Vámbéry am Donauufer“]. In: Vasárnapi Ujság Jg. 60, Nr. 39, v. 28.9.1913, coll. 772 a-b.

2. Ahmet Zeki Velidi: Vambery'nin eserleri ve eserlerinde Türklere nazarı. In: Türk Yurdu Bd. 5, Nr. 7, v. 12. Kanun-i Evvel 1329 (1913), pp. 1060-1065; Nr. 10, v. 12. Kanun-i Sani 1329 (1913), pp. 1153-1157.

3. Amittaj: Armin Vambéry. In: Izraelita. Tygodnik spoleczny-literacki Nr. 40, v. 3.10.1913, pp. $4-5$. 
4. Bató, Ludwig: Ein moderner Maranne. In: Die Welt Jg. 17, Nr. 40, v. 1.10.1913, coll. $1363 \mathrm{a}-1364 \mathrm{~b}$.

5. Bayer, F.: Hermann Vambéry (19. März 1832-15. September 1913). In: Österreichische Monatsschrift für den Orient Nr. 9 (1913), pp. 149-151.

6. Goth, Ernst: Hermann Vámbéry. In: Berliner Tageblatt Jg. 42, Nr. 479, v. 20.9.1913, ohne Seitenzahl.

7. Mészáros, Gyula: Vámbéry Armin 1831-1913. In: Történeti Szemle Jg. 2, Nr. 1 (1913), pp. 634-636.

8. Mészáros, Gyula: Vambery Armin 1831-1913. In: Türk Yurdu Bd. 5, Nr. 4, v. 17. Teşrin-i Evvel 1329 (1913), pp. 968-975.

9. nd: Vámbéry Ármin. In: Vasárnapi Ujság Jg. 60, Nr. 38, v. 21.9.1913, coll. 750 a-b.

10. Yavuz: Müsteşrik Vambery. In: Türk Yurdu Bd. 5, Nr. 4, v. 17. Teşrin-i Evvel 1329 (1913), pp. 962-968.

11. Zempléni, Árpád: Vámbéry halálára [dt. „Auf Vámbérys Tod“ (Vámbéry gewidmetes Gedicht)]. In: Turán Nr. 1 (1913), p. 60.

12. [ohne Vf.]: Arminius Vambery. Travel in Central Asia. In: The Times of India Bd. 76, Nr. 247, v. 16.10.1913, col. 6 f.

13. [ohne Vf.]: Arminius Vambery Dies at Buda Pest. Born a Jew and Won Fame as an Orientalist. In: The Boston Daily Globe Bd. 84, Nr. 78, v. 16.9.1913, coll. 2 a-b.

14. [ohne Vf.]: A Famous Orientalist. In: Hawera \& Normanby Star Bd. 65, Nr. 65, v. 8.11.1913, col. $12 \mathrm{c}$.

15. [ohne Vf.]: A Great Orientalist. In: Manawatu Standard Bd. 41, Nr. 9604, v. 23.9.1913, col. $2 \mathrm{~b}$.

16. [ohne Vf.]: Hermann Vambery und Sultan Abdul Hamid. In: Reichenberger Zeitung Nr. 333, v. 18.9.1913, coll. 17 b-c.

17. [ohne Vf.]: The Late Professor Vambery. In: The Jewish Herald (Melbourne) Jg. 34, Nr. 244, v. 7.11.1913, coll. 407 b-c.

18. [ohne Vf.]: Musul'manskaja pressa o Vamberi. In: Mir islama Jg. 2, Nr. 10 (1913), pp. $700-708$.

19. [ohne Vf.]: Professor Arminius Vambéry. In: Journal of the Royal Society of Arts Bd. 61, Nr. 3174, v. 19.9.1913, p. 975.

20. [ohne Vf.]: Professor Hermann Vambery. In: Trondhjems Adresseavis Jg. 147, Nr. 251, v. 24.9.1913, col. 2 d.

21. [ohne Vf.]: A Romantic Career. In: Evening Star Nr. 153115, v. 15.10.1913, col. 8 f.

22. [ohne Vf.]: Tyrkiets fremtid efter krigen [dt. „Die Zukunft der Türkei nach dem Krieg“]. In: Trondhjems Adresseavis Jg. 147, Nr. 214, v. 16.8.1913, coll. 2 a-b.

23. [ohne Vf.]: Vambéry. In: Kurjer Warszawski Jg. 93, Nr. 259, v. 19.9.1913, coll. 6 c-7 a.

24. [ohne Vf.]: Vambery and Persia. In: The Times of India Bd. 76, Nr. 250, v. 20.10.1913, col. 7 g. [enthält auch Abdruck e. Briefes v. Vámbéry v. 6.12.1912].

\section{6}

1. Murzaev, Ėd.: Chromoj derviš. In: Gazeta dlja vsech (Riga) Jg. 1, Nr. 23, v. 21.6.1936, pp. $8,18-19 ;$ Nr. 24 , v. 28.6.1936, p. 7-8. 
1. Trivedi, R. K.: British Imperial Interests and Vambery the Hungarian Turcologist. In: Proceedings of the Indian History Congress, Bd. 49 (1988), pp. 564-570.

1. Krizsán, László: Vámbéri [sic] Ármin Konstaninápolyi küldetése [dt. „Ármin Vámbérys konstantinopolitanischer Auftrag“]. In: Földrajzi múzeumi tanulmányok 8 (1990), pp. 66-67.

1. Zagorodnikova, T. N.: Perepiska V. V. Radlova i G. Vamberi (1867-1897). Vstupitel'naja stat'ja, sostavlenie i kommentarii. In: Vostok: Afro-Aziatskie Obščestva: Istorija i Sovremennost' Nr. 5 (1999), pp. 126-133.

1. Zajcev, Il'ja: Murad Ramzi i Arminij Vamberi. In: Gasyrlar Avazy - Écho Vekov 3/4 (2001), pp. $71-75$ [vgl. Nr. 738].

1. Yılmaz, Salih: Armín [sic] Vámbéry'nin Türkistan Seyahatnamesi'nde Geçen Ahmet İle Yusuf Destanı. In: Türk Dünyası Dil ve Edebiyat Dergisi 16 (2003), pp. 127-143.

2004

1. Yılmaz, Salih: İngiliz Casusu Armin Vambery'nin Türkistan Seyahatinde Ona Eşlik Eden Özbek İshak Molla Hakkında. In: TDAV Tarih Dergisi Nr. 211 (2004), pp. 51-56.

\section{5}

1. Hamilton, Keith: Dervishes, Dracula and Diplomacy. Arminius Vambéry and the British Foreign Office. In: The Records of the Permanent Under-Secretary's Department. Liaison between the Foreign Office and the British Secret Intelligence, 1873-1939 (Foreign \& Commonwealth Office Historians March 2005), o. O. (London) 2005, pp. 10-18.

2. Hamilton, Keith: Dervişler, Drakula ve Diplomasi. In: Toplumsal Tarih Nr. 23 (138), pp. $70-76$ [Übers. d. vorangegangenen Titels].

3. Keller, László: Abuška. Egy keleti-török szótár magyar kiadásának margójára [dt. „Abuška. Randbemerkungen zur ungarischen Ausgabe eines osttürkischen Wörterbuches"]. In: Dobrovits, Mihály (Hrsg.): A kisérlet folytatódik. II. Nemzetközi Vámbéry Konferencia, Dunaszerdahely, 2005: Lilium Aurum, pp. 83-89. 
4. Y1lmaz, Salih: Armin Vámbéry'nin Türkistan Seyahatnamesi ve Karakalpak Türklerine Dair Kayttlar. In: Belleten LXIX,255 (2005), pp. 599-628.

\section{6}

1. Valeev, R. K.; A. A. Gatin: Arminij Vamberi kak istorik kazanskich tatar. In: Učenye zapiski Kazanskogo gosudarstvennogo universiteta. T. 148, kn. 4. Gumanitarnye nauki (2006), pp. $53-61$.

\section{0}

1. Sárközy, Miklós: Vámbéry és a Bokhara története [dt. „Vámbéry und die Geschichte Bucharas"]. In: Vámbéry, Ármin: Bokhara története, a legrégibb időktöl a jelenkorig, ismert és ismeretlen keleti kézirati kútfók után. Dunaszerdahely, 2010: Lilium Aurum, pp. 485-499.

1. Felföldi, Szabolcs: Vámbéry Ármin és Stein Aurél kapcsolata [dt. „Die Beziehung zwischen Ármin Vámbéry und Aurél Stein“]. In: Dobrovits, Mihaly (Hrsg.): A Kelet ritka nyugalma. VII. Nemzetközi Vámbéry Konferencia, Dunaszerdahely, 2011: Lilium Aurum, pp. 91-104.

1. Akpınar, Turgut: Vámbéry, Arminius. In: Türkiye Diyanet Vakfi İslâm Ansiklopedisi Bd. 42, İstanbul, 2012, pp. 501-502.

2. Nazirova, H.: Vamberi Ogahiy bilan uchrashganmi? [dt. „Haben sich Vámbéry und [der Dichter] Āgahī getroffen?"] In: Xorazm Ma'mun Akademiyasi Axborotnomasi 3 (2012), pp. $20-23$.

3. Petrőczi, Éva: Vámbéry Ármin levele Viktória királynőnek, midőn szemében szánalmat látott [dt „Der Brief Ármin Vámbérys an Königin Victoria, als er in ihren Augen Mitleid sah“]. In: Tempevölgy Jg. 4, Nr. 14 (Juni 2012), pp. 56-57 [Vámbéry gewidmetes Gedicht].

\section{3}

1. Aslan, Margareta: From the Correspondence between Géza Kuun and Ármin Vámbéry. Documents. In: Studia et Documenta Turcologica (Cluj) Nr. 1 (2013), pp. 295-318.

2. Csorba, György: „Köszöntse Vámbéryt, ha ott van“. Vámbéry Ármin, az 1848-1849-es események és a negyvennyolcas emigráció [dt. „,Bitte grüße Vámbéry, wenn er dort ist! «. Ármin Vámbéry, die Ereignisse von 1848-1849 und die Emigration von 1848-49“]. In: Keletkutatás 2013, pp. 119-130.

3. Dávid, Géza: Vámbéry Ármin török krónikafordításai [dt. „Ármin Vámbérys Übersetzungen von türkischen Chroniken“]. In: Keletkutatás 2013, pp. 89-97. 
4. Kiss, László: Orvostörténészi vélekedés Vámbéry Ármin (1832-1913) „bénaságáról“ [dt. „Medizinhistorische Bemerkungen zur ,Lähmung“ Ármin Vámbérys (1832-1913)“]. In: Orvosi Hetilap Bd. 154, Nr. 36 (2013), pp. 1438-1440.

5. Papp, Sándor: Vámbéry Ármin és az oszmán történetírás [dt. „Ármin Vámbéry und die osmanische Geschichtsschreibung“]. In: Kelekutatás 2013, pp. 99-106.

6. Péri, Benedek: Fuzûlî egy ismeretlen verse Vámbéry Ármin Ćagataische Sprachstudien címü munkájában? [dt. „Ein unbekanntes Gedicht Fuzulîs in Ármin Vámbérys Ćagataischen Sprachstudien?"] In: Keletkutatás 2013, pp. 107-117.

7. Tafrešī, Mağīd: Siyāḥat-i yek darvīš-i durūgī̄n [dt. „Die Reise eines falschen Derwischs“]. In: Ğām-i ğam Nr. 3868, v. 28. Āzar 1392 (19.12.2013), coll. 11 e-f.

\section{4}

1. Aslan, Margareta: Fragmente din Istoria Transilvaniei, traduse de Vámbéry Ármin din cronica lui Silahdar Fındıklılı Mehmet Ağa [dt. „Von Ármin Vámbéry übersetzte Fragmente zur Geschichte Transsilvaniens aus der Chronik des Silahdar Fındıklılı Mehmet Ağa"]. In: Marian, Claudiu/Nicolescu, Corneliu (Hrsg.): Contemporaneitate şi provocările globalizării, Cluj-Napoca, 2014, pp. 303-327.

2. Aslan, Margareta: „Kirk Vezir“ în corespondenţele orientaliştilor Vámbéry Ármin şi Goldziher Ignácz [dt. „Kırk Vezir“ in der Korrespondenz der Orientalisten Ármin Vámbéry und Ignácz Goldziher"]. In: Anural Institutului de Istorie „George Bariţiu“ din Cluj-Napoca Bd. LIII (2014), pp. 313-336.

3. Rachmanova, Ju. M., Kamalova, N. P.: Arminij Vamberi - issledovatel' Central'noj Azii. In: Molodoj Učenyj Nr. 7 (66) (2014) pp. 577-578.

4. Sándor, Klára: Vámbéry Ármin és a török-magyar nyelvcsere. Vámbéry mint nyelvész [dt. „Ármin Vámbéry und der türkisch-ungarische Sprachaustausch. Vámbéry als Sprachwissenschaftler"]. In: Iskolakultúra 2/2014, pp. 77-86.

5. Zimonyi, István: Vámbéry Ármin magyar östörténeti képe a legújabb kutatások tükrében [dt. „Ármin Vámbérys Bild der ungarischen Vorgeschichte im Spiegel der jüngsten Forschungen“]. In: Keller, László (Hrsg.): Európából Ázsiába, és vissza ismét. XI. Nemzetközi Vámbéry Konferencia, Dunaszerdahely, 2014: Vámbéry Polgári Társulás, pp. 17-30.

\section{5}

1. Sárközy, Miklós (Hrsg.): Vámbéry (tanulmánykötet) [dt. „Vámbéry (Ein Band mit Studien)“], Dunaszerdahely, 2015: Lilium Aurum, 526 pp.

2. Apor, Éva: Vámbéry és a Qájárok. Adalékok [dt. „Vámbéry und die Qadjaren. Beiträge“]. In: Vámbéry (tanulmánykötet), pp. 459-470 [Wiederveröffentlichung v. Nr. 4.1.807].

3. Aslan, Margareta: Részletek Erdély történetéből. Vámbéry Ármin fordítása Silahdar Fındıklılı Mehmet Ağa krónikájából [dt. „Auszüge aus der Geschichte Siebenbürgens. Ármin Vámbérys Übersetzung aus der Chronik des Silahdar Fındıklılı Mehmet Ağa“"]. In: Keller, László (Hrsg.): Megcsalt reményünk. XII. Nemzetközi Vámbéry Konferencia, Dunaszerdahely, 2015: Vámbéry Polgári Társulás, pp. 31-60.

4. Csirkés, Ferenc: Vámbéry Ármin és az iráni politika [dt. „Vámbéry und die iranische Politik"]. In: Vámbéry (tanulmánykötet), pp. 367-390 [Wiederveröffentlichung v. Nr. 4.1.728].

5. Csirkés, Ferenc: Vámbéry Ármin és Közép-Ázsia [dt. „Ármin Vámbéry und Zentralasien“]. In: Vámbéry (tanulmánykötet), pp. 319-336 [Wiederveröffentlichung v. Nr. 4.1.742]. 
6. Çakırtaş, Önder: Said'in Şarkiyatçılık'ı Işığında Bir Okuma: Arminius Vambery'nin Travels In Central Asia Eseri ve Politik Teatrallik. In: Sosyal Araştırmalar Dergisi Bd. 3, Nr. 21, pp. 386-396.

7. Çolak, Melek: Macar Arşiv Belgelerinin Işığında Türkolog Vambery'nin Orta Asya Seyahati ve Yol Arkadaş1 Molla İshak Üzerine Düşünceler. In: Bilgin, Azmi (Hrsg.): XI. Milli Türkoloji Kongresi Bildirileri, 11-13 Kasım 2014, Bd. 2, İstanbul, 2015, pp. 363-389.

8. Dévényi, Kinga: Scholars in Private. On the Correspondence of Goldziher and Vámbéry. In: The Arabist. Budapest Studies in Arabic 36 (2015), pp. 35-45.

9. Dobrovits, Mihály: Vámbéry tudósi pályájáról [dt. „Über die wissenschaftliche Laufbahn Vámbérys"]. In: Vámbéry (tanulmánykötet), pp. 231-242 [Wiederveröffentlichung v. Nr. 4.1.729].

10. Felföldi, Szabolcs: Vámbéry Ármin és Stein Aurél a brit birodalmi eszmény szolgálatában [dt. „Ármin Vámbéry und Aurél Stein im Dienste des britischen imperialen Ideals“]. In: Vámbéry (tanulmánykötet), pp. 217-228 [Wiederveröffentlichung von Felföldi 2011].

11. Felföldi, Szabolcs: Vámbéry Ármin és Stein Aurél kapcsolata [dt. „Die Beziehung zwischen Ármin Vámbéry und Aurél Stein“]. In: Vámbéry (tanulmánykötet), pp. 159-171 [Wiederveröffentlichung v. Nr. 4.1.793].

12. Hazai, György: Egy Vámbéry Ármin által felfedezett magyar történelmi vonatkozású kézirat: a Tárih-i Ungurusz [dt. „Ein von Vámbéry entdecktes Manuskript zur ungarischen Geschichte: die Ta'rīh-i Ungurus“. In: Vámbéry (tanulmánykötet), pp. 243-261 [Wiederveröffentlichung v. Nr. 4.1.781].

13. Keller, László: Abuška. Egy keleti-török szótár magyar kiadásának margójára [„Abuška. Randbemerkungen zur ungarischen Ausgabe eines osttürkischen Wörterbuches"]. In: Vámbéry (tanulmánykötet), pp. 311-317 [Wiederveröffentlichung von Keller 2005].

14. Kiss, László: Egy 19. századi „paraolimpikon“ - orvostörténészi vélekedés Vámbéry Ármin „bénaságáról““ [dt. „Ein ,Paraolympionike“ des 19. Jahrhunderts - eine medizinhistorische Ansicht zu Ármin Vámbérys ,Lähmung““]. In: Vámbéry (tanulmánykötet), pp. 21-28 [Wiederveröffentlichung v. Nr. 4.1.744].

15. Kiss, László: Vámbéry Ármin és az első magyar kórboncnok, Arányi Lajos kapcsolata [dt. „Ármin Vámbéry und seine Beziehung zum ersten ungarischen Pathologen Lajos Arányi“"]. In: Vámbéry (tanulmánykötet), pp. 29-36. [Wiederveröffentlichung v. Nr. 4.1.773].

16. Kovács, Nándor Erik: Küzdők öröksége. Szilágyi Dániel, Vámbéry Ármin és Ibrahim Müteferrika emlékezete és az Akadémiai Könyvtár Keleti Gyüjteményének török kincsei [dt. „Das Erbe der Kämpfer. Erinnerungen an Dániel Szilágyi, Ármin Vámbéry und Ibrahim Müteferrika und die türkischen Schätze der Orientalischen Abteilung der Akademie-Bibliothek"]. In: Vámbéry (tanulmánykötet), pp. 349-363 [Wiederveröffentlichung v. Nr. 4.1.785].

17. Madaras, László: Vámbéry - és a kettős honfoglalás elmélete [dt. „Vámbéry und die Theorie der doppelten Landnahme"]. In: Vámbéry (tanulmánykötet), pp. 263-279 [Wiederveröffentlichung v. Nr. 4.1.810].

18. Németh, Pál: Kell-e választanunk Goldziher és Vámbéry közt? [dt. „Sollten wir zwischen Goldziher und Vámbéry wählen?"] In: Vámbéry (tanulmánykötet), pp. 143-158 [Wiederveröffentlichung v. Nr. 4.1.787].

19. Qasımov, Cavid: Orta Asya'nın Türk-İslam Şehirleri Armin Vamberi’nin Kayıtlarında. In: Doğan, D. Mehmet (Hrsg.): 3. Milletlerarası Şehir Tarihi Yazarları Kongresi (Türkiye Yazarlar Birliği Yayınları 56), Ankara, 2015, pp. 132-138.

20. Sárközy, Miklós: Felvidék és Erdély között: Vámbéry Ármin és az erdélyi Rhédey-kripta felújítása egy új dokumentumcsoport fényében [dt. „Zwischen Oberungarn und Siebenbürgen: Ármin Vámbéry und die Restaurierung der siebenbürgischen Krypta der Familie Rhédey 
im Lichte einer neuen Dokumentensammlung"]. In: Makkai, Béla (Hrsg.): A felvidék krónikása. Tanulmányok a 70 éves Popély Gyula tiszteletére, Budapest, 2015, pp. 151-159.

21. Sárközy, Miklós: Magyarok Persepolisban - Vámbéry és kortársainak emlékei az Achaimenida palotaváros árnyékában a 19. században [dt. „Ungarn in Persepolis. Erinnerungen an Vámbéry und seine Zeitgenossen im Schatten der achämenidischen Palaststadt im 19. Jahrhundert“]. In: Vámbéry (tanulmánykötet), pp. 391-410 [Wiederveröffentlichung v. Nr. 4.1.756].

22. Sárközy, Miklós: Mozaffar sah iráni uralkodó magyarországi utazása és naplója [dt. „Die ungarische Reise und das Reisetagebuch des Herrschers von Iran, Mozaffar Schahs"]. In: Vámbéry (tanulmánykötet), pp. 471-477.

23. Sárközy, Miklós: Nászer al-Dín perzsa sah útinaplója Magyarországról [dt. „Das Reisetagebuch Nașer ad-Dīn Schahs über Ungarn“]. In: Vámbéry (tanulmánykötet), pp. 411-458.

24. Sárközy, Miklós: Vámbéry Ármin felnőttkori családi viszonyai - vázlat a Vámbéry családról [dt. „Ármin Vámbérys Familienverhältnisse - Skizzen zu Vámbérys Familie“]. In: Vámbéry (tanulmánykötet), pp. 37-52 [Wiederveröffentlichung v. Nr. 4.1.824].

25. Sárközy, Miklós: Vámbéry Ármin levélkapcsolatai a brit konzervatív elittel [dt. „Ármin Vámbérys Korrespondenz mit der britischen konservativen Elite“]. In: Keller, László (Hrsg.): Megcsalt reményünk. XII. Nemzetközi Vámbéry Konferencia, Dunaszerdahely, 2015: Vámbéry Polgári Társulás, pp. 9-30.

26. Sárközy, Miklós: A Vámbéry családi archívum újrafelfedezése az Egyesült Államokban (Előzetes jelentés) [dt. „Die Wiederentdeckung des Familienarchivs Vámbéry in den Vereinigten Staaten (Vorläufiger Bericht)“]. In: Vámbéry (tanulmánykötet), pp. 53-81 [Wiederveröffentlichung v. Nr. 4.1.838].

27. Sárközy, Miklós: Vámbéry-tanulmányok - új utak a Vámbéry-kutatásban [dt. „VámbéryStudien - neue Wege in der Vámbéry-Forschung“]. In: Vámbéry (tanulmánykötet), pp. $5-17$.

28. Seres, István: A „Kubínyi-expedíció“, Thaly Kálmán és Vámbéry Ármin [dt. „Die „Kubínyi-Expedion, Kálmán Thaly und Ármin Vámbéry“]. In: Vámbéry (tanulmánykötet), pp. 115-142 [Wiederveröffentlichung v. Nr. 4.1.767].

29. Seres, István: Oroszhegyi Józsa és Vámbéry [dt. „Józsa Oroszhegyi und Vámbéry“]. In: Vámbéry (tanulmánykötet), pp. 173-204.

30. Seres, István: Vámbéry Ármin közép-ázsiai utazása a Budenz Józsefhez írott levelei tükrében [dt. „Die Zentralasienreise Ármin Vámbérys im Spiegel seiner Briefe an József Budenz"]. In: Vámbéry (tanulmánykötet), pp. 85-113 [Wiederveröffentlichung v. Nr. 4.1.735].

31. Sinkovics, Balázs: Vámbéry Ármin nézetei a nyelvrokonságról [dt. „Ármin Vámbérys Ansichten zur Sprachverwandtschaft“]. In: Vámbéry (tanulmánykötet), pp. 281-296 [Wiederveröffentlichung v. Nr. 4.1.825].

32. Šafranskaja, Ėleonora: „Špion“ Arminij Vamberi. In: Zvezda Nr. 8 (2015), pp. 206-218.

33. Vásáry, István: Vámbéry, Ömer Feridun és a Szózat törökül [dt. „Vámbéry, Ömer Feridun und der Szózat \{,Aufruf', Mihály Vörösmartys patriotisches Gedicht, eine Art inoffizieller ungarischer Nationalhymne\} auf Türkisch“. In: Vámbéry (tanulmánykötet), pp. 337-348 [Wiederveröffentlichung v. Nr. 4.1.751].

34. Vér, Márton: A Küzdelmeim orientalizmusa? [dt. „Orientalismus in Küzdelmeim?"]. In: Vámbéry (tanulmánykötet), pp. 205-215 [Wiederveröffentlichung v. Nr. 4.1.806].

35. Zimonyi, István: Vámbéry Ármin magyar őstörténeti képe a legújabb kutatások tükrében [dt. „Ármin Vámbérys Bild der ungarischen Vorgeschichte im Spiegel der jüngsten For- 
schungen“]. In: Vámbéry (tanulmánykötet), pp. 297-307 [korrigierte Fassung von Zimonyi 2014].

\section{6}

1. Felföldi, Szabolcs: „,Fény metszette élet“. Vámbéry-album [dt. „,Ein Leben, durch Licht geformt«. Ein Vámbéry-Album“]. Dunaszerdahely, 2016: Vámbéry Polgári Társulás.

2. Çolak, Melek: Osmanlı İmparatorluğu, İngiltere ve Rusya Açısından Vámbéry'nin Orta Gezisi Üzerine Düşünceler. In: Belleten Bd. 130, Nr. 289 (2016), pp. 885-900.

3. Sárközy, Miklós: Személyiség és keletkutatás: Vámbéry Ármin és identitásai [dt. „Persönlichkeit und Orientalistik: Ármin Vámbéry und seine Identitäten“]. In: Sepsi, Enikő u. a. (Hrsg.): Nyelv, kultúra, identitás. A Károli Gáspár Református Egyetem 2015-ös évkönyve, Budapest, 2016, pp. 31-47.

4. S̆afranskaja, Ėleonora: Arminij Vamberi: kul'turnyj podvig orientalista. In: Smirnova, A. I. (Hrsg.): Russkaja literatura i kul tura v polietničeskoj srede i meždisciplinarnom kontekste sovremennogo obrazovanija, Moskva, 2016, pp. 108-127.

5. Šafranskaja, Ėleonora: Karazin i Vamberi. In dies.: Turkestanskij tekst v russkoj kul'ture: Kolonial'naja proza Nikolaja Karazina (istoriko-literaturnyj i kul'turno-ètnografičeskij kommentarij), Sankt-Peterburg, 2016, pp. 292-297.

6. Zajcev, Il'ja: Murad Remzi ve Ármin Vámbéry. In: Tarih Okulu Dergisi XXVII (2016), pp. 635-643 [Übersetzung von Zajcev 2001].

\section{7}

1. Bernád, Á. Z.: Vámbéry Ármin (Hermann). In: Österreichisches Biographisches Lexikon Bd. 15 (Lieferung 68), Wien, 2017, pp. 170-171.

2. Konrád, Miklós: De l'orthodoxie juive au sionisme en passant par la conversion: le parcours juif d'Ármin Vámbéry (1832-1913). In: Ferruta, Paola/Dumont, Martin/Tollet, Daniel (Hrsg.): Entre judaïsme et christianisme: Le conversions en Europe, de l'époque moderne à l'apparition de l'antisemitisme politique, Paris-Louvain-Bristol, 2017, pp. $185-205$.

3. Kovács, Attila: Utazás Dunaszerdahely-Szeged viszonylatban: Vámbéry Ármintól Vámbéry Árminig [dt. „Eine Reise von Dunaszerdahely nach Szeged: Von Ármin Vámbéry zu Ármin Vámbéry“]. In: Belvedere Meridionale 30.3 (2017), pp. 172-174.

4. Sárközy, Miklós: Vámbéry Ármin és Teck Victoria Mary királyné (V. György brit uralkodó felesége) levelezése [dt. „Die Korrespondenz zwischen Ármin Vámbéry und Königin Victoria Mary von Teck (der dominanten Ehefrau George V.)“]. In: Keller, László (Hrsg.): Teljes tárgyilagosság és szigorú valóság. XIII. Nemzetközi Vámbéry Konferencia, Dunaszerdahely, 2017, pp. 199-217.

5. Markusková, Helena: Armin Vámbéry svetoznámy cestovatel' zo Svätého Jura [dt. „Ármin Vámbéry, ein weltbekannter Reisender aus Svätý Jur (Sankt Georgen)“]. In: Historika Jg. 6, Nr. 1, pp. 27-32.

6. Tajták, Ladislav: Slovanské starožitnosti v diele Ármina Vámbéryho Zrod a rozmnožovanie Mad’arov [dt. „Die Slawischen Altertümer [Pavol Jozef Šafáriks] in Ármin Vámbérys Werk Die Entstehung und Ausbreitung des Ungarntums"]. In: Sedláková, Marianna/Gladiš (Hrsg.): Pavol Jozef Šafárik v kontinuite (Acta Facultatis Philosophicae Universitatis Šafarikianae 104 (2017)), pp. 85-89. 
7. Tulaşoğlu, Gülay: 1882 'de Macarların Türklüğünü İspat İçin Girişilmiş Bir Çaba: Armin Vambery'nin Der Ursprung Der Magyaren Adlı Çalışması. In: Şahin, İlhan u. a. (Hrsg.): Altay Communities. History Issues, İstanbul, 2017, pp. 303-336.

8. Vásáry, István: Bilim Adamı Ármin Vámbéry. In: Türk Tarihi Araştırmaları Dergisi Bd. 2, Nr. 1 (2017), pp. 112-123 [Übersetzung von Nr. 4.1.826 durch Alev Duran].

\section{Rezensionen von Werken A. Vámbérys}

\section{4}

1. [ohne Vf.]: Arminius Vámbéry's Reisen durch Turkistan nach Samarcand. In: Das Ausland Jg. 37, Nr. 52, v. 24.12.1864, coll. 1225 a-1234 a [Rez. zu Nr. 34].

2. [ohne Vf.], [ohne Titel]. In: The London and China Telegraph Bd. VI, Nr. 157, v. 5.12.1864, pp. 686-687 [Rez. zu Nr. 34].

\section{5}

1. Briquet, A.: Voyages d'un faux derviche. In: Bibliothèque universelle et revue suisse, Bd. 23 (1865), pp. 400-450, 563-624; Bd. 24, pp. 252-309 [Rez. zu Nr. 45].

2. G. H.: Vámbéry's Reisen in Central-Asien I. Die Abenteuer des ungarischen Derwisch. In: Magazin für die Literatur des Auslandes Nr. 19, v. 6.5.1865, coll. 261 b-264 a [Rez. zu Nr. 45].

3. G. H.: Vámbéry's Reisen in Central-Asien II. Die politischen Verhältnisse von Turan. In: Magazin für die Literatur des Auslandes 20, v. 13.5.1865, coll. 278 a-279 a [Rez. zu Nr. 45].

4. Jonveaux, Émile: Un faux derviche dans le Turkestan. In: Le Correspondant Bd. 66 (1865), pp. 23-69 [Rez. zu: Nr. 34, Nr. 45 und Nr. 46].

5. [ohne Vf.]: Boukharie. M. Vambéry. Les voyageurs hongrois à la recherche des origines magyares. In: L'année géographique Bd. 3 (1865), pp. 166-178 [Rez. zu Nr. 34].

6. [ohne Vf.]: Central Asia. In: The Manchester Guardian Nr. 5784, 3.1.1865, coll. $3 \mathrm{a}-\mathrm{d}$ [Rez. zu Nr. 34].

7. [ohne Vf.]: Central Asia. In: The New Monthly Magazine Bd. 133 (1865), pp. 127-142 [Rez. zu Nr. 34].

8. [ohne Vf.]: De Lotgevallen van een Hongaar in Middel-Azië [dt. „Die Abenteuer eines Ungarn in Mittelasien"]. In: Wetenschappelijke bladen Teil 3 (1865), pp. 123-168 [Rez. zu Nr. 34, Übers. v. Nr. 5.18].

9. [ohne Vf.]: Podróże Vambery’ego po środkowej Azji [dt. „Die Reisen Vámbérys durch Zentralasien“"]. In: Dziennik Literacki Jg. 13, Nr. 70, v. 5.9.1865, coll. 562 b-564 a [Rez. zu Nr. 34].

10. [ohne Vf.]: Putešestvie Vamberi v Sr. Aziju. In: Otečestvennye Zapiski Nr. 17 (1865), pp. 103-141; Nr. 18 (1865), pp. 314-348; Nr. 19 (1865), pp. 401-441 [Rez. zu Nr. 45].

11. [ohne Vf.]: Vambery's Travels. In: New-York Daily Tribune Bd. 25, Nr. 7542, v. 8.6.1865, coll. 6 a - b [Rez. zu Nr. 34].

12. [ohne Vf.], [ohne Titel]. In: Kavkaz Jg. 20, Nr. 10, v. 4.2.1865, coll. 53 a-c [Rez. zu Nr. 34]. 
13. [ohne Vf.], [ohne Titel]. In: Morgenblatt für gebildete Leser 13, v. 26.3.1865, pp. 305-308 [Rez. zu Nr. 34].

14. [ohne Vf.], [ohne Titel]. In: Wolfgang Menzels Literaturblatt 26, v. 1.4.1865, pp. 101-104 [Rez. zu Nr. 45].

\section{6}

1. J. M.: [ohne Titel]: in Journal Asiatique Bd. 10 (1867), p. 518 [Rez. zu Nr. 84].

2. Jonveaux, Émile: A Pretended Dervish in Turkestan. Translated from Le Correspondant. In: Catholic World Bd. 3 (1866), pp. 198-215, 390-403 [Rez. zu: Nr. 34, Nr. 45 und Nr. 46].

3. [ohne Vf.]: Putešestvie v Chivu i v Bucharu v 1863 godu. In: Voennyj Sbornik Bd. 47 (1866), pp. 325-360; Bd. 48 (1866), pp. 155-184 [Rez. zu Nr. 34].

4. [ohne Vf.], [ohne Titel]. In: Revue Critique des Livres Nouveaux Bd. 34 (1866), pp. 16-18 [Rez. zu Nr. 46].

\section{7}

1. [ohne Vf.]: Ny litteratur. In: Borgå-Bladet Nr. 2, v. 12.1.1867, ohne Seitenzahl [dt. „Neue Literatur"; Rez. zu Nr. 68].

\section{8}

1. B.: Vambéry's ethnographische Skizzen aus Mittelasien. In: Zeitschrift der Gesellschaft für Erdkunde zu Berlin Bd. 3 (1868), pp. 278-280 [Rez. zu Nr. 104].

2. Grigor'ev, V.: Očerki Srednej Azii. Dopolnenija k moemu putešestviju v te kraja. In: Izvestija Imperatorskogo Russkogo Geografičeskogo Obščestva IV (1868), pp. 305-308 [Rez. zu Nr. 104].

3. Il: Ármin Vámbéry: Vándorlásaim és élményeim Persiában [dt. „Meine Wanderungen und Erlebnisse in Persien“"]. In: Budapesti Szemle Bd. 10 (1868), pp. 322-325 [Rez. zu Nr. 86].

4. [ohne Vf.]: Hermann Vámbéry in Persien. In: Das Ausland Jg. 41, Nr. 9, v. 27.2.1868, coll. 193 a-197 b [Rez. zu Nr. 85].

5. [ohne Vf.]: Sketches in Central Asia. In: The Saturday Review Nr. 646, Bd. 25, pp. $361-$ 363 [Rez. zu Nr. 103].

6. [ohne Vf.]: Turkestanisches von Vámbéry. In: Das Ausland Jg. 41, Nr. 17, v. 23.4.1868, coll. 385 a-389 b [Rez. zu Nr. 104].

7. [ohne Vf.], [ohne Titel]. In: Beilage zur Allgemeinen Zeitung Nr. 194, v. 12.7.1868, coll. 2953 b-2955 a [Rez. zu Nr. 84].

8. [ohne Vf.], [ohne Titel]. In: The Examiner Nr. 3128, v. 11.1.1868, coll. $20 \mathrm{a}-\mathrm{c}$ [Rez. zu Nr. 103].

9. [ohne Vf.], [ohne Titel]. In: Literarisches Centralblatt für Deutschland Nr. 6, v. 1.2.1868, coll. $142-144$ [Rez. zu Nr. 84].

10. [ohne Vf.], [ohne Titel]. In: Westermann's Jahrbuch der Illustrirten Deutschen Monatshefte Bd. 24 (1868), p. 98 [Rez. zu Nr. 85].

11. [ohne Vf.], [ohne Titel]. In: Wolfgang Menzels Literaturblatt Nr. 8, v. 25.1.1868, pp. 2932; Nr. 9, v. 29.1.1868, pp. $33-35$ [Rez. zu Nr. 85]. 
12. [ohne Vf.], [ohne Titel]. In: Wolfgang Menzels Literaturblatt Nr. 24, v. 21.3.1868, pp. $93-$ 96.[Rez. zu Nr. 104].

13. [ohne Vf.]: Skizzen aus Mittel-Asien von Vámbéry. In: Neue Dörptsche Zeitung Nr. 125 (1868) [Rez. zu Nr. 104].

>Turkestanskij Sbornik 1868 Bd. 8, Sanktpeterburg, 1869, pp. 270-274.

14. [ohne Vf.], [ohne Titel]. In: Russkij Invalid Nr. 50 (1868) [Rez. zu Očerki Srednej Azii, Moskva 1868].

>Turkestanskij Sbornik 1868 Bd. 8, Sanktpeterburg, 1869, p. 255.

1. L. A.: Očerki Srednej Azii. In: Vestnik Evropy T. 5 Kn. 9 (1869), pp. $253-257$ [Rez. zu Očerki Srednej Azii sowie von Galkin, M. N.: Ėtnografičeskie i istoričeskie materialy po Srednej Azii i Orenburgskomu kraju, Sanktpeterburg, 1869, und v. Pašino, P. I.: Turkestanskij kraj v 1866 godu. Putevye zametki, Sanktpeterburg, 1868].

2. [ohne Vf.]: Stranstvovanija po Persii. In: Izvestija Imperatorskogo Russkogo Geografičeskogo Obščestva IV (1868), St. Peterburg, 1869, p. 253. [Rez. zu Nr. 85].

1870

1. Choroškin, A. P.: Neskol'ko zametok po povodu knigi Vamberi: „Putešestvie po Srednej Azii“. In: Voennyj Sbornik Bd. 81 (1870), pp. 38-48 [Rez. zu Nr. 43].

1. E.: Rußlands Machtstellung in Asien. In: Allgemeine Schweizerische Militär-Zeitung. Organ der schweizerischen Armee XVII, 47 (1871), p. 382 [Rez. zu Nr. 175].

2. Kuun, Géza: [o. T.]. In: La Rivista europea Jg. 2, Bd. 2 (1871), pp. 362-365 [Rez. zu Nr. 149].

3. M. L.: [o. T.]. In: Literarisches Centralblatt für Deutschland Nr. 29, v. 22.7.1871, coll. 728 b729 a [Rez. zu Nr. 175].

\section{2}

1. [ohne Vf.]: Rußlands Machtstellung in Asien. In: Österreichische Wochenschrift für Wissenschaft und Kunst Bd. 1 (1872), pp. $45-49$ [Rez. zu Nr. 175].

1. D'Istria, Dora: La poésie populaire des turcs orientaux. In: Revue des deux Mondes Bd. 103 (1873), pp. 543-583 [Sammelrez.von Nr. 45, Nr. 46, Nr. 84, Nr. 104 sowie weiterer Werke anderer Autoren].

2. Lerch, P.: [ohne Titel]. In: Russische Revue Bd. 2 (1873), pp. 588-589 [Rez. zu Nr. 204]. 
3. Pavet de Courteille, A.: [ohne Titel]. In: Journal Asiatique 7 Serie, Bd. I, Paris, 1873, pp. 377-412 [Rez. zu Nr. 149].

4. Šujler, Evgenij [= Schuyler, Eugene]: Naskol'ko dostoverny rasskazy Vamberi o Srednej Azii? In: Kavkaz Jg. 28, Nr. 144, v. 9.12.1873, coll. 2 d-e [Übers. v. Nr. 5.52].

5. Yule, H.: History of Bokhara. In: Ocean Highways: The Geographical Review April 1873, pp. 20-23 [Rez. zu 205].

6. [ohne Vf.]: Bokhara the Holy. In: The Saturday Review Bd. 35, Nr. 897, v. 4.1.1873, pp. 20-21 [Rez. zu Nr. 194 und Nr. 205].

7. [ohne Vf.]: German Literature. In: The Saturday Review Bd. 36, Nr. 925, v. 19.7.1873, pp. 95-96, hier p. 95 [Sammelrez. zu Nr. 204 und weiteren Werken anderer Autoren].

8. [ohne Vf.]: Neue Werke über Centralasien. In: Die Grenzboten. Zeitschrift für Politik, Literatur und Kunst 32. Jg. (1873), pp. 401-408 [Rez. zu Nr. 194 und zu Nr. 204].

9. [ohne Vf.]: Vambery's Geschichte von Bokhara. In: Magazin für die Literatur des Auslandes 42. Jahrg. Nr.7, v. 15.2.1873, p. 106 [Rez. zu Nr. 205].

10. [ohne Vf.], [ohne Titel]. In: The British Quarterly Review Bd. 57 (1873), pp. 514-516 [Rez. zu Nr. 205].

11. [ohne Vf.], [ohne Titel]. In: Militair-Wochenblatt Nr. 46, v. 28.5.1873, p. 410 [Rez. zu Nr. 104 und Nr. 175].

12. [ohne Vf.]: O perevode „Istorii Buchary“ Vamberi na russkij jazyk. In: Golos Nr. 224 (1873) [Rez. zu Nr. 206].

> Turkestanskij Sbornik Bd. 72, Sanktpeterburg, 1873, pp. 92-93.

\section{4}

1. Feer, L.: [o. T.]. In: Revue critique d'histoire et de littérature Bd. 16, Nr. 36, v. 5.9.1874, pp. $145-150$ [Rez. zu Nr. 194]

2. Zöllner, Reinhart: Vámbéry und die centralasiatische Frage. In: Blätter für literarische Unterhaltung Nr. 33, v. 13.8.1874, coll. 513 a-516 b [Rez. zu Nr. 204].

3. [ohne Vf.]: Professor Vambery on the Russian-Asian Question. In: The Argus (Melbourne) Nr. 8724, v. 30.5.1874, coll. 4 a-b [Rez. zu Nr. 232].

4. [ohne Vf.]: Vambéry's Central Asia. In: Saturday Review of Politics, Literature, Science and Art Bd. 37, Nr. 965, v. 25.4.1874, coll. 534 a-535 b [Rez. zu Nr. 232].

5. [ohne Vf.], [ohne Titel]. In: Literarisches Centralblatt für Deutschland Nr. 18, v. 2.5.1874, coll. 591-592 [Rez. zu Nr. 204].

\section{5}

1. Goergens: [ohne Titel]. In: Theologisches Literaturblatt Jg. 10, Nr. 11, v. 23.5.1875, coll. 254-260 [Rez. zu Nr. 243].

2. M. B.: Der Islam im neunzehnten Jahrhundert. In: Magazin für die Literatur des Auslandes Jg. 44, Nr. 22, v. 29.5.1875, coll. 326 a-327 b [Rez. zu Nr. 243].

3. Websky, J.: Islam oder Christenthum? In: Protestantische Kirchenzeitung für das evangelische Deutschland Nr. 35, v. 28.8.1875, coll. 808-811 [Rez. zu Nr. 243].

4. [ohne Vf.], [ohne Titel]. In: Algemeen Handelsblad Nr. 14317, v. 2.10.1876, ohne Seitenzahl [Rez. zu Nr. 243].

5. [ohne Vf.], [ohne Titel]. In: Literarisches Centralblatt für Deutschland Nr. 41, v. 9.10.1875, coll. 1313-1314 [Rez. zu Nr. 243]. 
1. Chmielowski, P.: [ohne Titel]. In: Gazeta Polska Nr. 223, v. 10.10.1876, coll. 3 b-d; Nr. 224, v. 11.10.1876, coll. 3 d-4 a [Rez. zu Nr. 262.a].

2. Jabłonowski, Aleksander: Wschód muzułmański [dt. „Der muslimische Orient“]. In: Ateneum Bd. III (1876), Nr. 10, pp. 178-194; Nr. 11, pp. 113-137 sowie in Jabłonowski, Aleksander: Pisma Aleksandra Jabłonowskiego Tom VI: Wschód muzułmański, Warszawa, 1912, pp. 1-55 [Rez. zu Nr. 262.a].

3. Lorm, Hier.: „Sittenbilder aus dem Morgenlande“. In: Die Neue Zeit. Olmüzer politische Zeitung Nr. 176, v. 25.7.1876, p. 6 [Rez. zu Nr. 264].

4. Soury, Jules: Revue des livres étrangers d'octobre. In: Le Temps Nr. 5668, v. 23.10.1876, ohne Seitenzahl [Rez. zu Nr. 243 und weiteren Büchern anderer Autoren].

5. [ohne Vf.]: Die Frauen des Orients. In: Tagespost (Graz) 145, v. 27.6.1876, pp. 1-3 [Rez. zu Nr. 264 mit längerem Zitat].

6. [ohne Vf.]: Vambery's Buch über „Ganz-Asien“. In: Neues Wiener Tagblatt (Tages-Ausgabe) 169 , v. 21.6.1876, p. 20 [Rez. zu. Nr. 264].

7. [ohne Vf.], [ohne Titel]. In: Algemeen Handelsblad Nr. 14317, v. 25.10.1876, ohne Seitenzahl [Rez. zu Nr. 276].

1. Brandes, Edvard: Kulturskildringer fra Orienten [dt. „Skizzen zur Kultur des Orients“]. In: Det Nittende Aarhundrede. Maanedskrift for Literatur og Kritik Bd. 3, Juni-Juli (1877), pp. 339-340 [Rez. zu: Kulturskildringer fra Orienten, Kjøbenhavn, 1877: Andr. Fred. Høst \& Søns forlag, 352 pp.].

2. [ohne Vf.], [ohne Titel]. In: Delo. Žurnal literaturno-političeskij Bd. 11, Nr. 2, pp. 92-107 [Rez. zu Nr. 264].

3. [ohne Vf.], [ohne Titel]. In: Literarisches Centralblatt für Deutschland Nr. 25, v. 16.6.1877, coll. 815-816 [Rez. zu Nr. 284].

\section{8}

1. Pavet de Courteille: [ohne Titel]. In: Journal Asiatique Serie 7, Bd. 12, pp. 208-216 [Rez. zu Nr. 305].

\section{9}

1. [ohne Vf.], [ohne Titel]. In: Literarisches Centralblatt für Deutschland Nr. 21, v. 24.5.1879, coll. 678-680 [Rez. zu Nr. 305].

\section{0}

1. [ohne Vf.], [ohne Titel]. In: Literarisches Centralblatt für Deutschland Nr. 36, v. 4.9.1880, coll. 1190-1192 [Rez. zu Nr. 328]. 
1. Barbier de Meynard: [ohne Titel]. In: Revue Historique, Bd. 16, Nr. 1 (1881), pp. 197-199 [Rez. zu Nr. 328].

\section{3}

1. [ohne Vf.]: Arminius Vambery. In: Times of India Bd. 46 N.S., Nr. 286, v. 6.12 .1883 [sic], col. 6 e [Rez. zu Nr. 407].

\section{4}

1. Gy: [ohne Titel]. In: Földrajzi Közlemények Bd. 12 (1884), p. 141 [Rez. zu Nr. 407]

2. Stratilatov, M.: Vvedenie k soč. Vamberi „Pervobytnaja kul'tura tjurko-tatarskich narodov“. In: Zapiski Zapadno-Sibirskogo otdelenija Russkogo geografičeskogo obščestva 1884, kn. 6, pp. 1-49 [Rez. zu Nr. 328; keine durchgehende Seitenzählung des Bandes].

3. Zimmern, H.: Vambéry's Leben, von ihm selbst beschrieben. In: Die Presse Nr. 39, v. 9.2.1884, pp. 1-3 [Rez. zu Nr. 407].

4. [ohne Vf.]: Arminius Vambery. In: The Australasian (Melbourne) Jg. 37, Nr. 965, v. 27.9.1884, coll. 584a-c [Rez. zu Nr. 407].

5. [ohne Vf.]: Arminius Vambery: His Life and Adventure. In: West Coast Times Nr. 4604, v. 28.4.1884, ohne Seitenzahl [Rez. zu Nr. 407].

6. [ohne Vf.]: A Famous Traveler. In: New York Times Bd. 33, Nr. 10221, v. 8.6.1884, coll. 5 a-b [Rez. zu Nr. 407].

7. [ohne Vf.], [ohne Titel]. In: Calcutta Review Bd. 79, Nr. 157 (Juli 1884), pp. X-XV [Rez. zu Nr. 407].

8. [ohne Vf.], [ohne Titel]. In: The Dublin Review Bd. 12, Nr. 1(1884), pp. 230-232 [Rez. zu Nr. 407].

9. [ohne Vf.], [ohne Titel]. In: The London Quarterly Review Bd. 2, Nr. 124 (Juli 1884), pp. 387-389 [Rez. zu Nr. 407].

\section{5}

1. K.: Der Zukunfts-Kampf um Indien. In: Marburger Zeitung (Maribor) Nr. 151, v. 20.12.1885, pp. $2-4$ [Rez. zu Nr. 452].

2. [ohne Vf.]: Russia and England in Central Asia. In: New York Times Bd. 34, Nr. 10612, v. 7.9.1885, coll. 2 f-g [Rez. zu Nr. 421].

3. [ohne Vf.], [ohne Titel]. In: Beilage zur Bohemia Nr. 344, v. 15.12.1885, col. 2 b [Rez. zu Nr. 452].

\section{6}

1. Czirbusz, Géza: La race turque. Le livre d'Arminius Vámbéry. In: Abrégé du Bulletin de la Société Hongroise de Géographie Jg. 14, pp. 26-37 [frz. Übers. v. Nr. 2 des laufenden Jahres]. 
2. Czirbusz, Géza: A török faj. Vámbéry Ármin könyve [dt. „Die türkische Rasse. Ármin Vámbérys Buch“]. In: Földrajzi Közlemények Jg. 14 (1886), pp. 75-85 [Rez. zu Nr. 419].

3. J. P.: Hermann Vámbéry: Das Türkenvolk. In: Beilage zur Allgemeinen Zeitung Nr. 131 (1886), v. 12.5.1886, coll. 1921 a-1923 a [Rez. zu Nr. 423].

4. Lm.: [ohne Titel]. In: Mittheilungen der kaiserlich-königlichen Geographischen Gesellschaft XXIX (1886), pp. 407-408 [Rez. zu Nr. 452].

5. - -s.: [ohne Titel]. In: Budapesti Szemle Nr. 114 (1886), pp. $473-484$ [Rez. zu Nr. 419].

6. [ohne Vf.], [ohne Titel]. In: Literarisches Centralblatt für Deutschland Nr. 49, v. 27.11.1886, coll. 1682-1863 [Rez. zu Nr. 423].

7. [ohne Vf.], [ohne Titel]. In: Literarisches Centralblatt für Deutschland Nr. 19, v. 1.5.1886, col. 655 [Rez. zu Nr. 452].

8. [ohne Vf.], [ohne Titel]. In: Le Siècle Jg. 51, Nr. 18279, v. 7.1.1886, ohne Seitenzahl [Rez. zu Nr. 449].

\section{7}

1. Campbell, J. W. R.: ,Life and Adventures' of Arminius Vambéry. In: The Wesleyan-Methodist Magazine Bd. 11 (Januar 1887), pp. 24-32 [Rez. zu Nr. 448].

2. G. H.: [ohne Titel]. In: Historische Zeitschrift Bd. 57, H. 2 (1887), pp. 371-374 [Rez. zu Nr. 423].

3. [ohne Vf.]: The Story of Hungary. In: The Observer Nr. 5023, v. 28.8.1887, coll. $6 \mathrm{c}-\mathrm{d}$ [Rez. zu Nr. 466].

\section{9}

1. G. v. d. G.: [o. T.]. In: Literarisches Centralblatt für Deutschland Nr. 47, v. 16.11.1889, col. 1615 [Rez. zu Nr. 422].

\section{0}

1. G. W. L.: The Sarts and Their Language. In: Asiatic Quarterly Review Bd. 10 (Juli 1890), pp. $465-466$ [Rez. zu Nr. 532].

\section{5}

1. [ohne Vf.], [ohne Titel]. In: Földrajzi Közlemények Jg. 32, pp. 185-186 [Rez. zu Nr. 581].

2. [ohne Vf.], [ohne Titel]. In: Abrégé du Bulletin de la Société Hongroise de Géographie. XXIII Année (1895), pp. 33-34 [franz. Übers. v. Nr. 1 d. laufenden Jahres].

\section{6}

1. Marczali, Henrik: [ohne Titel]. In: Budapesti Szemle Nr. 331 (1896), pp. 381-384 [Rez. zu Nr. 581]. 
1. Beauvois, E.: [ohne Titel]. In: Revue critique d'histoire et de littérature Nr. 51, v. 8.12.1899, pp. 494-495 [Rez. zu Nr. 618].

2. [ohne Vf.], [ohne Titel]. In: Annales de géographie Nr. 47 (1899), p. 7 [Rez. zu Nr. 622].

\section{4}

1. B. M.: Vámbéry emlékirataiból. In: Vasárnapi Ujság Jg. 51, Nr. 51, coll. 869 a-870 c [dt. „Über Vámbérys Erinnerungen“; Rez. zu Nr. 670].

2. Ch. J.: [ohne Titel]. In: Földrajzi Közlemének Jg. 32 (1904), p. 296 [Rez. zu Nr. 668].

3. E. v. Ch.: [ohne Titel]. In: Abrégé du Bulletin de la Société Hongroise de Géographie. Supplément au XXX. [sic] Volume des „Földrajzi Közlemények“ (1904), p. 100 [franz. Übers. der. vorangegangenen Rez. zu Nr. 668].

4. g. gy.: Vámbéry Ármin emlékiratai [dt. „Ármin Vámbérys Erinnerungen“]. In: Budapesti Szemle Nr. 336 (1904), pp. 451-461 [Rez. zu Nr. 670].

5. [ohne Vf.]: An Orientalist's Memoirs. In: The Times of India Bd. 67, Nr. 292, v. 9.12.1904, col. 7e [Rez. zu Nr. 670].

6. [ohne Vf.]: Vambéry the Wanderer. In: Saturday Review of Politics, Literature, Science and Art Bd. 98, Nr. 2556, v. 22.10.1904, coll. 518 a-b. [Rez. zu Nr. 670].

\section{5}

1. d.: [ohne Titel]. In: Budapesti Szemle Nr. 337 (1905), pp. 145-147 [Rez. zu Nr. 668].

2. [ohne Vf.]: Arminius Vambery. The Autobiography of a Self-Made Man. In: New-York Tribune Illustrated Supplement Bd. 64, Nr. 21238, v. 8.1.1905, coll. 6 a-c [Rez. zu Nr. 670].

3. [ohne Vf.]: Professor Vambery's Autobiography. In: The Sydney Morning Herald Nr. 20980, v. 3.6.1905, coll. 4 e-f [Rez. zu Nr. 670].

\section{6}

1. A. J. L.: [ohne Titel]. In: The North-China and Supreme Court \& Consular Gazette Bd. 84, Nr. 2025, v. 1.6.1906, coll. 488 b-c [Rez. zu Nr. 686].

2. L. B.: [ohne Titel]. In: Mitteilungen der kaiserlich-königlichen Geographischen Gesellschaft in Wien Nr. 49 (1906), pp. 614-618 [Rez. zu Nr. 687].

3. Mandel, Ernő: Vámbéry tanár legujabb angol munkája... [dt. „Die neueste englische Veröffentlichung von Prof. Vámbéry“]. In: Nagybánya és Vidéke Jg. 32, Nr. 35, v. 2.9.1906, coll. 2 a-c [Rez. zu Nr. 686].

4. Wirth, A.: West-östliche Wechselwirkungen. In: Beilage zur Allgemeinen Zeitung Nr. 271, v. 12.11.1906, coll. 355 b-357 a [Rez. zu Nr. 687].

5. [ohne Vf.]: West vs. East. Prof. Vambery's Study of European and Asiatic Racial and Political Contrasts. In: New York Times, v. 28.7.1906 Bd. 55, Nr. 17717, coll. 471 a-b [Rez. zu Nr. 686].

6. [ohne Vf.], [ohne Titel]. In: Chicago Daily Tribune Bd. 65, Nr. 218, v. 6.9.1906, col. 8 e [Rez. zu Nr. 686]. 
7. [ohne Vf.], [ohne Titel]. In: Revue du monde musulman Bd. 1, Nr. 1 (November 1906), pp. 133-134 [Rez. zu Nr. 686].

\section{8}

1. R. C.: Cichy bohater [dt. „Ein stiller Held“] . In: Izraelita. Tygodnik spoteczny, literacki $i$ naukowy Jg. 43, Nr. 16., v. 17.4.1908, coll. 151 c-152 c; Nr. 17, v. 1.5.1908, coll. 162 c164 b; Nr. 18, v. 8.5.1908, coll. 173 c-174 c [Rez. zu Nr. 670].

\section{5}

1. Á. L.: [ohne Titel]: In: Irodalomtörténet 4 (1915), pp. 352-354 [Rez. zu Nr. 753].

\section{Literaturverzeichnis}

Galambos, Ferenc 1978-1979. A Vasárnapi Ujság repertóriuma 1854-1921, 8 Bände. Budapest. Online: URL: http://mek.oszk.hu/12900/12941/pdf/ [letzter Zugriff 06.02.2019].

KNÜPPEL, Michael 2013. 'Nachträge zur Bio-Bibliographie von Ármin(ius) Vámbéry [III].' Zeitschrift für Balkanologie 49/1: 92-102.

KNÜPPEL, Michael 2017. Ármin(ius) Vámbéry (1832-1913) - Versuch einer Personalbibliographie. [2., verbesserte Auflage.] Nordhausen: Verlag Traugott Bautz.

Mežov, Vladimir I. [Владимир Измайлович Межов] 1878, 1884, 1888. Туркестанский сборник сочиненій и статей, относящихся до средней Азіи вообще и Туркестанскаго края в особенности: систематическій и азбучные указатели сочиненій и статей на русском и иностранном языках. I-II-III. Санктпетербург. 